Preliminary Assessment of Landslides Along the Florida River Downstream From Lemon Reservoir, La Plata County, Colorado

Open-File Report 2006-1343 


\section{Preliminary Assessment of Landslides Along the Florida River Downstream From Lemon Reservoir, La Plata County, Colorado}

By William H. Schulz, Jeffrey A. Coe, William L. Ellis, and John D. Kibler

Open-File Report 2006-1343 


\section{U.S. Department of the Interior DIRK KEMPTHORNE, Secretary}

\section{U.S. Geological Survey \\ Mark D. Myers, Director}

\section{U.S. Geological Survey, Reston, Virginia: 2006}

For product and ordering information:

World Wide Web: http://www.usgs.gov/pubprod

Telephone: 1-888-ASK-USGS

For more information on the USGS — the Federal source for science about the Earth, its natural and living resources, natural hazards, and the environment:

World Wide Web: http://www.usgs.gov

Telephone: 1-888-ASK-USGS

Any use of trade, product, or firm names is for descriptive purposes only and does not imply endorsement by the U.S. Government.

Although this report is in the public domain, permission must be secured from the individual copyright owners to reproduce any copyrighted materials contained within this report.

Suggested citation:

Schulz, W.H., Coe, J.A., Ellis, W.L., and Kibler, J.D., 2006, Preliminary assessment of landslides along the Florida River downstream from Lemon Reservoir, La Plata County, Colorado: U.S. Geological Survey Open-File Report 2006-1343, 29 p., 1 plate, map scale 1:2,770. 


\section{Contents}

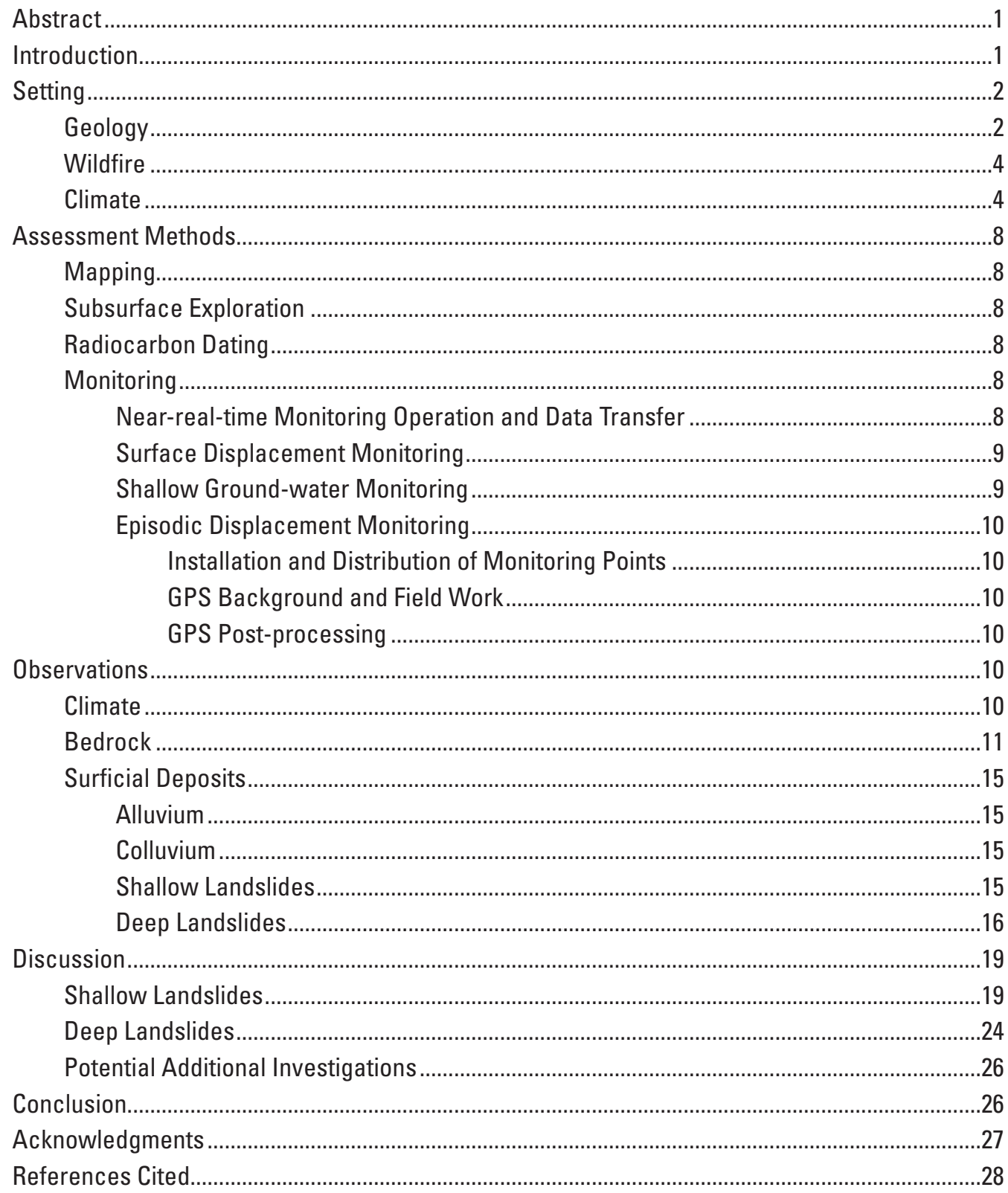

\section{Figures}

1. Map showing the location of the Florida River landslide complex, Lemon Reservoir, and La Plata County roadways. Approximate locations of residential structures identified using 2003 La Plata County aerial photography are indicated by red circles.

2. Climate data measured at Lemon Dam, October 1, 1982 - May 31, 2006. Data obtained from the Western Regional Climate Center, Desert Research Institute. 
3. Percentage of average precipitation measured at Lemon Dam for the period of October 1 - April 30 of water years 1982 - 2005. Climate data obtained from the Western Regional Climate Center, Desert Research Institute

4. Percentage of average precipitation measured at Durango for the period of October 1 - April 30 of water years $1900-2004$. Climate data obtained from the Western Regional Climate Center, Desert Research Institute

5. Climate data measured at Lemon Dam, October 1, 2004 - September 30, 2005. Data obtained from the Western Regional Climate Center, Desert Research Institute...

6. Climate data measured at Lemon Dam, October 1, 1983 - September 30, 1984. Data obtained from the Western Regional Climate Center, Desert Research Institute.

7. Climate data measured at Lemon Dam, October 1, 1992 - September 30, 1993. Data obtained from the Western Regional Climate Center, Desert Research Institute

8. Head of a translational landslide that was active during spring 2005 within the Florida River landslide complex. Headscarp in upper part of photograph is $3.2 \mathrm{~m}$ high

9. Lateral shear zone along the margin of a translational landslide that was active during spring 2005 within the Florida River landslide complex. Landslide is on the right side of the ground fracture. Trees along shear zone are about $0.3 \mathrm{~m}$ in diameter.

10. Toe of a translational landslide that was active during spring 2005 within the Florida River landslide complex. The toe is thrusting over the leaning tree that is about $0.4 \mathrm{~m}$ in diameter.......

11. Deposit of a debris flow mobilized from a shallow landslide that was active during spring 2005 within the Florida River landslide complex.

12. Source area, flow track, and part of a deposit of a debris flow mobilized from a shallow landslide that was active during spring 2005 within the Florida River landslide complex. Trees are 0.1-0.3 $\mathrm{m}$ in diameter.

13. Climate data measured at Lemon Dam, February 20, 2005 - April 16, 2005 ..

14. Extensometer (CET) data measured within the Florida River landslide complex, May 22, 2005 - July 7, 2006.

15. Piezometer data measured within the Florida River landslide complex, May 24, 2005 - July 7, 2006.

16. Virtual view to the southeast of the Florida River landslide complex. The older bedrock landslide is outlined in yellow and shallow landslides active during spring 2005 are outlined in white. View was created using a GIS by draping an orthophotograph and digital line graphs of mapped landslide boundaries onto the DEM

17. Virtual view to the northeast of the Florida River landslide complex. The older bedrock landslide is outlined in yellow and shallow landslides active during spring 2005 are outlined in white. View was created using a GIS by draping an orthophotograph and digital line graphs of mapped landslide boundaries onto the DEM.

\section{Tables}

1. Survey monument coordinates and standard GPS error ${ }^{1}$. 


\section{Conversion Factors}

\begin{tabular}{lcl}
\hline Multiply & By & \multicolumn{1}{c}{ To obtain } \\
\hline centimeter $(\mathrm{cm})$ & Length & \\
meter $(\mathrm{m})$ & 0.3937 & inch $(\mathrm{in})$. \\
kilometer $(\mathrm{km})$ & 3.281 & foot $(\mathrm{ft})$ \\
& 0.6214 & mile $(\mathrm{mi})$ \\
\hline square meter $\left(\mathrm{m}^{2}\right)$ & Area & acre \\
square meter $\left(\mathrm{m}^{2}\right)$ & 0.0002471 & square foot $\left(\mathrm{ft}^{2}\right)$ \\
\hline & 10.76 & \\
\hline cubic meter $\left(\mathrm{m}^{3}\right)$ & Volume & gallon $(\mathrm{gal})$ \\
cubic meter $\left(\mathrm{m}^{3}\right)$ & 264.2 & cubic yard $\left(\mathrm{yd}^{2}\right)$ \\
\hline & 1.308 & \\
\hline cubic meter per day $\left(\mathrm{m}^{3} / \mathrm{d}\right)$ & Flow rate & cubic foot $\mathrm{per} \mathrm{day}\left(\mathrm{ft}^{3} / \mathrm{d}\right)$ \\
\hline
\end{tabular}




\title{
Preliminary Assessment of Landslides Along the Florida River Downstream from Lemon Reservoir, La Plata County, Colorado
}

\author{
By William H. Schulz, Jeffrey A. Coe, William L. Ellis, and John D. Kibler
}

\section{Abstract}

Nearly two-dozen shallow landslides were active during spring 2005 on a hillside located along the east side of the Florida River about one kilometer downstream from Lemon Reservoir in La Plata County, southwestern Colorado. Landslides on the hillside directly threaten human safety, residential structures, a county roadway, utilities, and the Florida River, and indirectly threaten downstream areas and Lemon Dam. Most of the area where the landslides occurred was burned during the 2002 Missionary Ridge wildfire. We performed geologic mapping, subsurface exploration and sampling, radiocarbon dating, and shallow ground-water and grounddisplacement monitoring to assess landslide activity. Active landslides during spring 2005 were as large as $35,000 \mathrm{~m}^{3}$ and confined to colluvium. Debris flows were mobilized from most of the landslides, were as large as $1,500 \mathrm{~m}^{3}$, and traveled as far as $250 \mathrm{~m}$. Landslide activity was triggered by elevated groundwater pressures within the colluvium caused by infiltration of snowmelt. Landslide activity ceased as ground-water pressures dropped during the summer. Shallow landslides on the hillside appear to be much more likely following the Missionary Ridge fire because of the loss of tree root strength and evapotranspiration. We used monitoring data and observations to develop preliminary, approximate rainfall/snowmelt thresholds above which shallow landslide activity can be expected. Landslides triggered during spring 2005 occurred within a $1.97 \times 10^{7}$ $\mathrm{m}^{3}$ older landslide that extends, on average, about $40 \mathrm{~m}$ into bedrock. The south end of this older landslide appears to have experienced deep secondary landsliding. Radiocarbon dating of sediments at the head of the older landslide suggests that the landslide was active about 1,424-1,696 years ago. A relatively widespread wildfire may have preceded the older landslide, and the landslide may have occurred during a wetter time. The wetter climate and effects of the wildfire would likely have resulted in increased ground-water pressures, which may have triggered the older landslide. This landslide appears to have crossed the valley floor and been subsequently eroded from this area. We found no evidence that landslide debris across the valley floor formed an impoundment of the Florida River, although it is very likely. Erosion of buttressing landslide debris from the valley floor and the lower strength of the landslide basal shear zone relative to pre-slide strength created less stable conditions than were present prior to occurrence of the landslide. However, deep ground-water conditions largely control the stability of the slope and are unknown here; hence, the potential for future deep landsliding is unknown. Additional investigation could be undertaken to further characterize landslide hazards in the area. This investigation could include episodic surveying of monuments we installed across the older landslide, obtaining detailed topographic data and aerial photography, mapping landslide debris and lacustrine deposits related to the potential former landslide dam, mapping secondary landslides, obtaining additional ages of landslide activity, constructing deep boreholes and ground-water monitoring wells, laboratory testing of soil and rock strength and hydraulic properties, and groundwater and slope-stability modeling.

\section{Introduction}

Several active landslides were observed by area residents during April 2005 on a hillside above the Florida River and County Road 243 (CR-243) in La Plata County, southwestern Colorado. Mr. John Ey, Superintendent of the Florida Water Conservancy District (FWCD), and Mr. N.D. Knowlton, La Plata County Director of Emergency Preparedness, contacted personnel of the U.S. Geological Survey (USGS) Landslide Hazards Program and requested assistance in evaluating the landslide activity. The landslide area occupies a hillside located 0.9-1.6 km downstream from Lemon Dam (fig. 1), which impounds the Florida River creating Lemon Reservoir. Lemon Dam is an earthfill dam completed in 1963 and owned by the U.S. Bureau of Reclamation (USBR) (http://www.usbr.gov/ dataweb/dams/co01688.htm, accessed March 13, 2006). The dam is operated by the FWCD. The hillside on which the landslides occurred was burned during the 2002 Missionary Ridge wildfire. Landslide activity during April 2005 coincided with rapid melting of a heavy, wet snow pack (J. Ey and M. Radosevich, pers. commun., 2005). This snow pack was produced by the highest precipitation level to that point in the water year (October 1 - September 30) since 1941 (J. Ey, pers. commun., 2005). 
Initial USGS reconnaissance identified at least 10 landslides that partly or wholly mobilized as debris flows (rapidly moving mixtures of silt, sand, and boulders, capable of longdistance travel). These landslides appeared to average about two meters (m) thick, $25 \mathrm{~m}$ long, and $25 \mathrm{~m}$ wide, and appeared to occur within larger active landslides with lengths and widths on the order of $100 \mathrm{~m}$. All of the active landslides (that is, landslides active during spring 2005) appeared to be located within a much larger, older bedrock landslide approximately $500 \mathrm{~m}$ long and 1,300 $\mathrm{m}$ wide, forming a landslide complex. This older landslide appeared to have previously crossed the Florida River valley floor, most likely damming the river. Landslide activity within the complex threatens human safety, residential structures, CR-243 and utilities aligned along the roadway, and the Florida River and areas downstream. Potential landslide-caused impoundment of the Florida River potentially threatens Lemon Dam; its toe is about $20 \mathrm{~m}$ higher than the valley floor downslope from the landslide complex. Lemon Dam impounds the primary water supply for the City of Durango, Colorado. To assess landslide activity on the hillside, we performed engineering geologic mapping, laboratory testing of soil ages, monitoring of shallow ground-water conditions and surface displacement from May 2005 through July 2006, and analysis of our findings. The results of our assessment are presented herein.

\section{Setting}

The Florida River landslide complex is located on a westfacing hillside along the east side of La Plata CR-243 and the Florida River (fig. 1). The landslide complex is located on both private and public land (San Juan National Forest, administered by the U.S. Forest Service [USFS]). The hillside on which the landslide complex occurs has an average inclination of about $29^{\circ}$ but includes vertical and flat sections. This hillside is located along the west side of a south-trending series of mountains that form part of the hydrologic divide between the Florida River basin and the Los Piños River basin. The terminus of this series of mountains is located a few hundred meters south of the landslide complex at about the location of CR-240 (fig. 1). The Florida River valley floor downslope from the landslide complex is at an elevation of about $2400 \mathrm{~m}$, whereas the crest of the hillside above the landslide complex is at an elevation of about $2750 \mathrm{~m}$.

The Florida River generally drains from Lemon Dam southward for about $2.5 \mathrm{~km}$ before turning southwest at the intersection of Spring Gulch, which parallels CR-240 east of CR-243 (fig. 1). Homes are scattered on the banks and floodplain of the Florida River downstream from the landslide complex. The valley floor immediately downstream from the dam is generally between 175-300 m wide, except below the landslide complex where it is between 110-130 m wide. Several residential structures occupy the valley floor downslope from the landslide complex on both the east and west sides of CR-243.

\section{Geology}

The Florida River landslide complex is located along the southern margin of the San Juan dome, a structure formed during the Laramide uplift that resulted in the San Juan Mountains (Steven and others, 1974; Tweto, 1975). Bedrock units directly beneath the landslide complex have a southerly inclination due to their location on the south side of the dome. The landslide complex occurs mostly within Cretaceous age (144-65 million years ago [Ma]) sedimentary rocks of the Dakota Sandstone and Burro Canyon Formation, and within Jurassic age (206-144 Ma) sedimentary rocks of the Morrison Formation, Junction Creek Sandstone, Wanakah Formation, and Entrada Sandstone (Carroll and others, 1997). Plate 1 shows the geologic mapping of Carroll and others (1997) outside the boundaries of the landslides mapped during our study. The bedrock units are typically light-colored sandstones and some conglomerates with minor amounts of fine-grained rocks and coal, with the exceptions of the Morrison Formation and Wanakah Formation. The Morrison Formation is primarily composed of greenish-gray and lesser amounts of reddish-brown mudstone, whereas the Wanakah Formation is primarily white to tan, reddish-orange to reddish-brown sandstone and mudstone, and gray limestone. Bedrock units strike to the west-northwest and typically dip $10-15^{\circ}$ to the south. In-situ measurements and ground-water flow modeling of conditions present in the San Juan structural basin provide estimated vertical and horizontal hydraulic conductivity values of $2.5 \times 10^{-6}$ and $2.5 \times 10^{-2} \mathrm{~m} / \mathrm{d}$, respectively, for the Morrison Formation, and $3.4 \times 10^{-4}$ and $0.15 \mathrm{~m} / \mathrm{d}$ for the Entrada Sandstone (Frenzel and Lyford, 1982). The San Juan structural basin is located immediately south of the landslide complex and is about $250 \mathrm{~km}$ across.

Carroll and others (1997) show Holocene (10,000 years ago to present) and late Pleistocene (279 thousand years ago [Birkeland, 1999, p. 171] to 10,000 years ago) colluvium mantling much of the hillside where the landslide complex occurs, and alluvium along the Florida River valley floor. The colluvium ranges from sandy, pebble gravel to boulder gravel to gravelly sand or clayey silt. The alluvium consists of silt, sand, gravel, and boulders.

Blair (1977) produced a surficial geologic map that shows geologic hazards in the landslide area. He mapped a large landslide within the boundaries of the older landslide shown on plate 1; his mapped landslide and that mapped during our study have somewhat different boundaries. He also mapped the surrounding hillside as potentially unstable. The results of his mapping are available at the La Plata County geographic information system (GIS) website (http://arcims.laplata.co.us/ laplataWEBSITE/, last accessed March 13, 2006).

Figure 1 (following page). Map showing the location of the Florida River landslide complex, Lemon Reservoir, and La Plata County roadways. Approximate locations of residential structures identified using 2003 La Plata County aerial photography are indicated by red circles. 


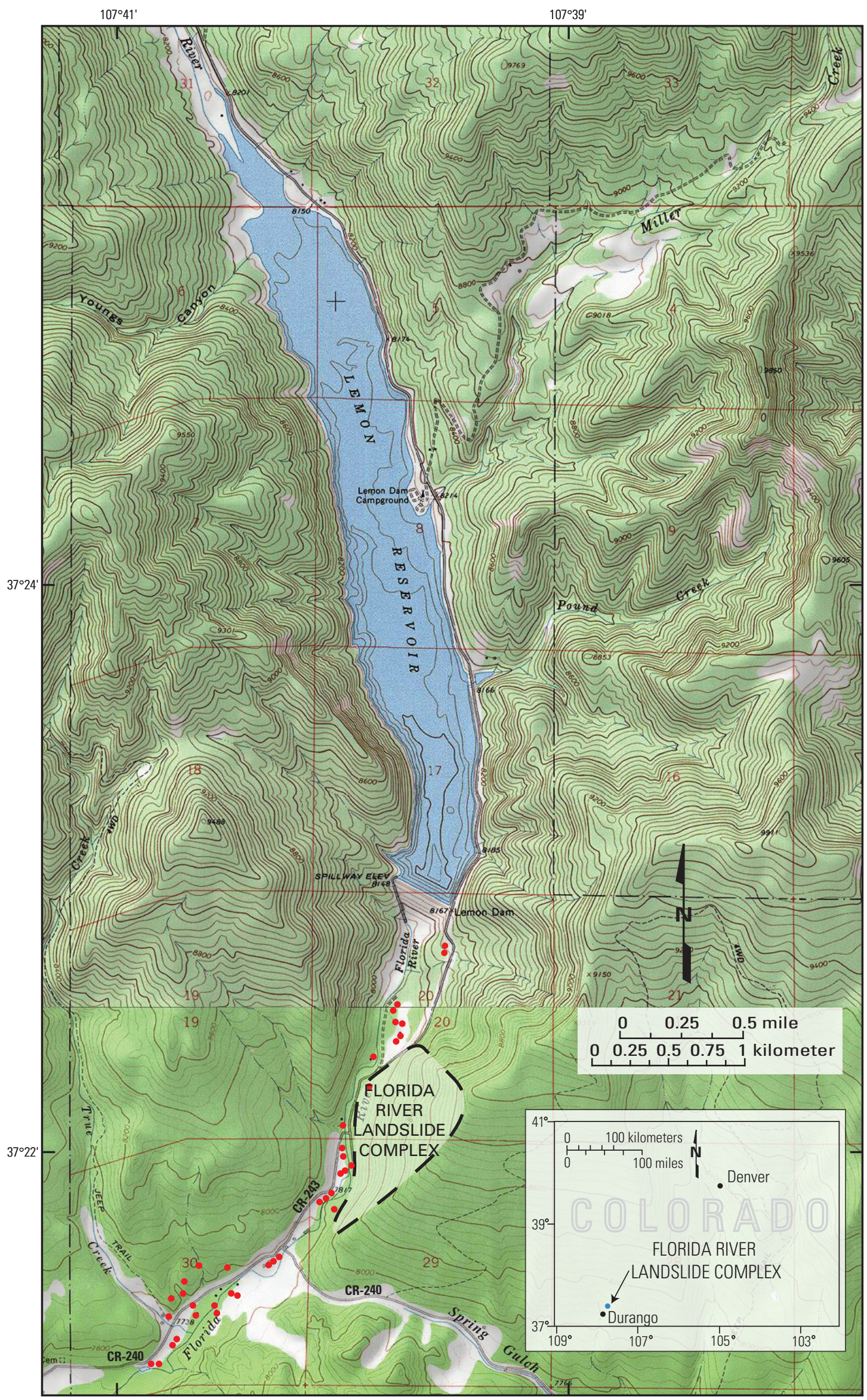


The Florida River valley was largely shaped to its present configuration during Pleistocene glaciation $(1,800,000$ $-10,000$ years ago). The approximate present form of the valley was created during the Durango stage of glaciation, which occurred during the early Pleistocene (Atwood and Mather, 1932). The Durango glacier in the Florida River valley advanced just beyond the mouth of Miller Creek (fig. 1) where it deposited moraines and till. Most of these deposits now occur beneath the waters of Lemon Reservoir. During melt off of the Durango glacier, stream flow carved the Florida River valley to its approximate present level near the landslide complex (Atwood and Mather, 1932). The Wisconsin stage of glaciation followed the Durango stage and occurred during late Pleistocene time. The Wisconsin glacier in the Florida River valley advanced almost as far as Miller Creek (Atwood and Mather, 1932) and receded about 11,000 years ago (Toney and Anderson, 2006). Most of the alluvium in the valley near the landslide complex was probably deposited by streams issuing from Wisconsin glacier meltwaters (Atwood and Mather, 1932). Little stream erosion or aggradation has occurred during the Holocene in the Florida River valley near the landslide complex (Atwood and Mather, 1932).

\section{Wildfire}

Most of the area around the landslide complex was burned during the 2002 Missionary Ridge wildfire. Burn severity was generally classified as moderate to severe in the landslide area (U.S. Forest Service, 2002, pl. 1). During summer 2006, many dead standing trees remained on the hillside, while ground cover and aspen (1-3 m tall) had begun revegetating the area.

Wildfire, such as the Missionary Ridge fire, may result in runoff-generated debris flows following heavy precipitation and snowmelt events (for example, Cannon, 2001; Cannon and others, 2003; Smith and others, 2003). Runoff-generated debris flows occurred on many hillsides near the landslide complex following the Missionary Ridge fire during 2002. For example, large runoff-generated debris flows occurred on the hillside opposite the landslide complex, burying the CR-243 bridge over the Florida River (J. Ey, pers. commun., 2005). However, the landslides within the Florida River landslide complex are not of the runoff-generated type that often follows wildfire. The landslides within the complex are discrete ground failures bounded by shear surfaces. Shallow landslides of this type have been observed to preferentially occur following wildfire beginning about 4-15 yrs after the fire and persisting for 10-20 yrs (DeGraff, 1997). Shaub (2001) studied widespread landslide activity that occurred in a forested, mountainous area of Idaho that was partly burned by wildfire during 1989. She studied 246 landslides that were triggered by $28 \mathrm{~cm}$ of rain that fell on $35 \mathrm{~cm}$ of snow during a one-week period at the end of 1996 and beginning of 1997. She found that landslide density in burned areas was more than three times greater than in unburned areas. Cannon and Gartner (2005) noted that wildfires often result in decreased tree root strength and increased soil moisture, both of which can promote landsliding. These three previous studies all note that landslides triggered following wildfire are typically shallow and primarily involve surficial soil and colluvium.

The Florida River landslide area has been burned by wildfire many times. Dating of wildfire-related debris-flow deposits in the Florida River basin within a kilometer of the landslide complex and in the Los Piños River basin about 11 kilometers northeast of the landslide complex identified wildfires 130, 800, 1,100, 1,610, 2,500, 2,800, 3,000, 3,200, and $4,000{ }^{14} \mathrm{C}$ yrs before present (J.D. Frechette, University of New Mexico, written commun., 2006; Frechette and others, 2003; Gonzales and others, 2003; Gonzales and others, 2005). Dating of tree rings, forest regeneration events, and alluvial deposits in the Los Piños River basin identified wildfires during the years $1879,1851,1818,1806,1770,1750,1730$, and 1680 , and a high-severity fire $2,500{ }^{14} \mathrm{C}$ yrs before present (as did Frechette), or 2,200 calibrated calendar years before present (E. Bigio, University of Arizona, written commun., 2006; Bigio and others, 2005).

\section{Climate}

Postglacial climate trends for the area have been estimated based on sediment coring at Little Molas Lake (Toney and Anderson, 2006), located about $40 \mathrm{~km}$ north from the landslide complex and about $800 \mathrm{~m}$ higher. Glacial retreat occurred about 11,200 yrs ago at Little Molas Lake due to general warmer and drier conditions. Widespread drought occurred between about 6,200-4,200 yrs ago. Conditions became wetter, possibly with winter precipitation, between about 2,650-1,250 yrs ago. Conditions then became relatively drier and persist at present.

The FWCD operates a weather station near Lemon Dam, less than a kilometer from the landslide complex. Figure 2 shows climate data measured at Lemon Dam since 1982, with cumulative precipitation calculated for each water year. A water year is defined as October 1 through September 30, with the water-year name corresponding with the year the water year began. Snowmelt that occurred prior to spring 2005 landslide activity within the complex was above average, but not extreme. Cumulative precipitation for the Lemon Dam period of record was greater for complete water years 1996 and 1998 than for 2004, although cumulative precipitation until April 30 was greatest for water year 2004 (fig. 3). Figure 4 shows the percentage of average precipitation that fell each water year by the end of April measured in Durango, approximately $22 \mathrm{~km}$ southeast from the landslide complex. Durango data provide a longer period of record (1900-2004) than Lemon Dam data. Although Durango data (fig. 4) do not directly correlate with measurements made at Lemon Dam (for example, 2004 precipitation in Durango was less than that of three other years during the Lemon Dam period of record whereas precipitation was greatest at Lemon Dam during 2004), general trends are consistent. Since 1900 in Durango, 14 years experienced significantly more water-year precipitation through April than water year 2004 (fig. 4). 


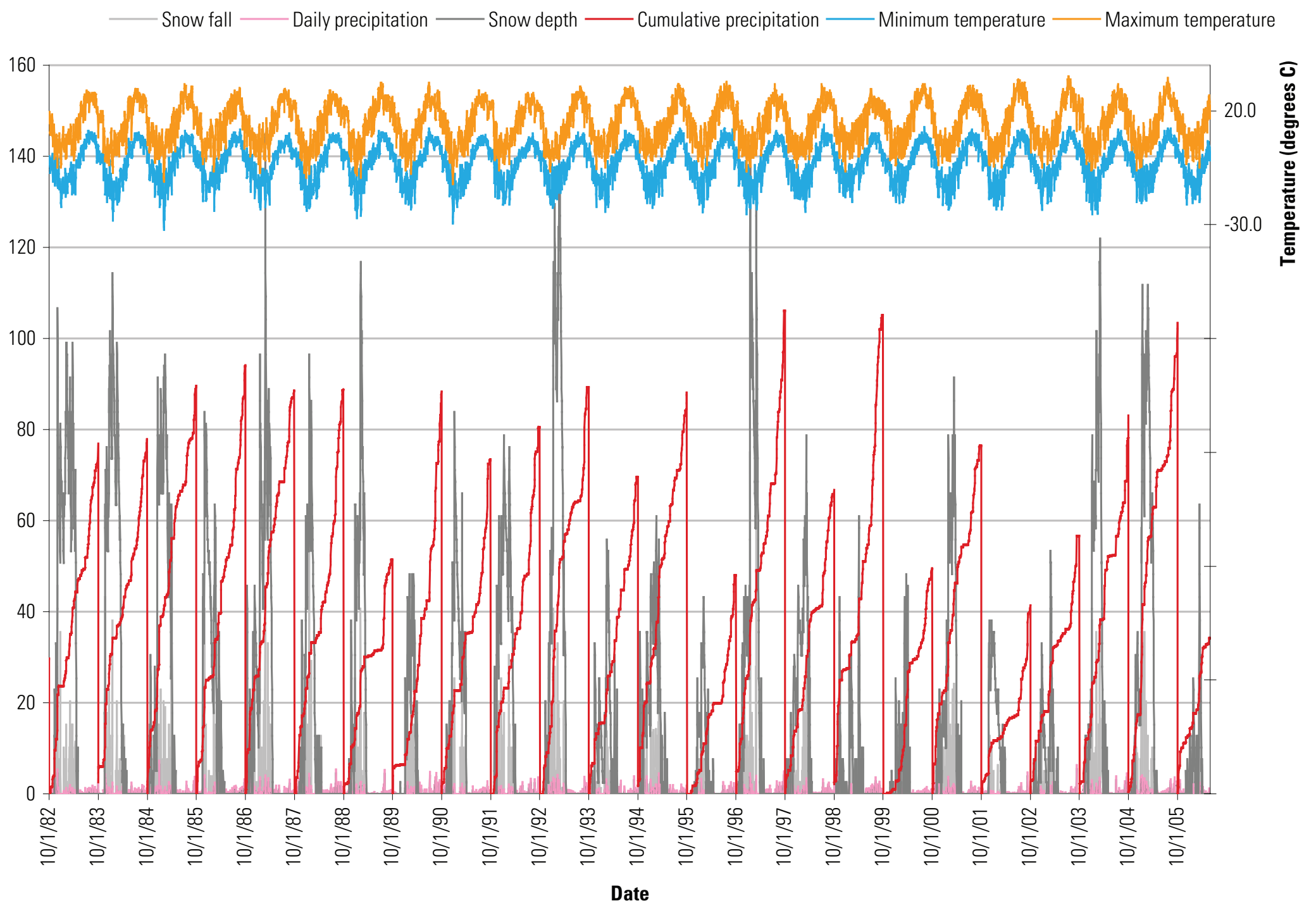

Figure 2. Climate data measured at Lemon Dam, October 1, 1982 - May 31, 2006. Data obtained from the Western Regional Climate Center, Desert Research Institute. 


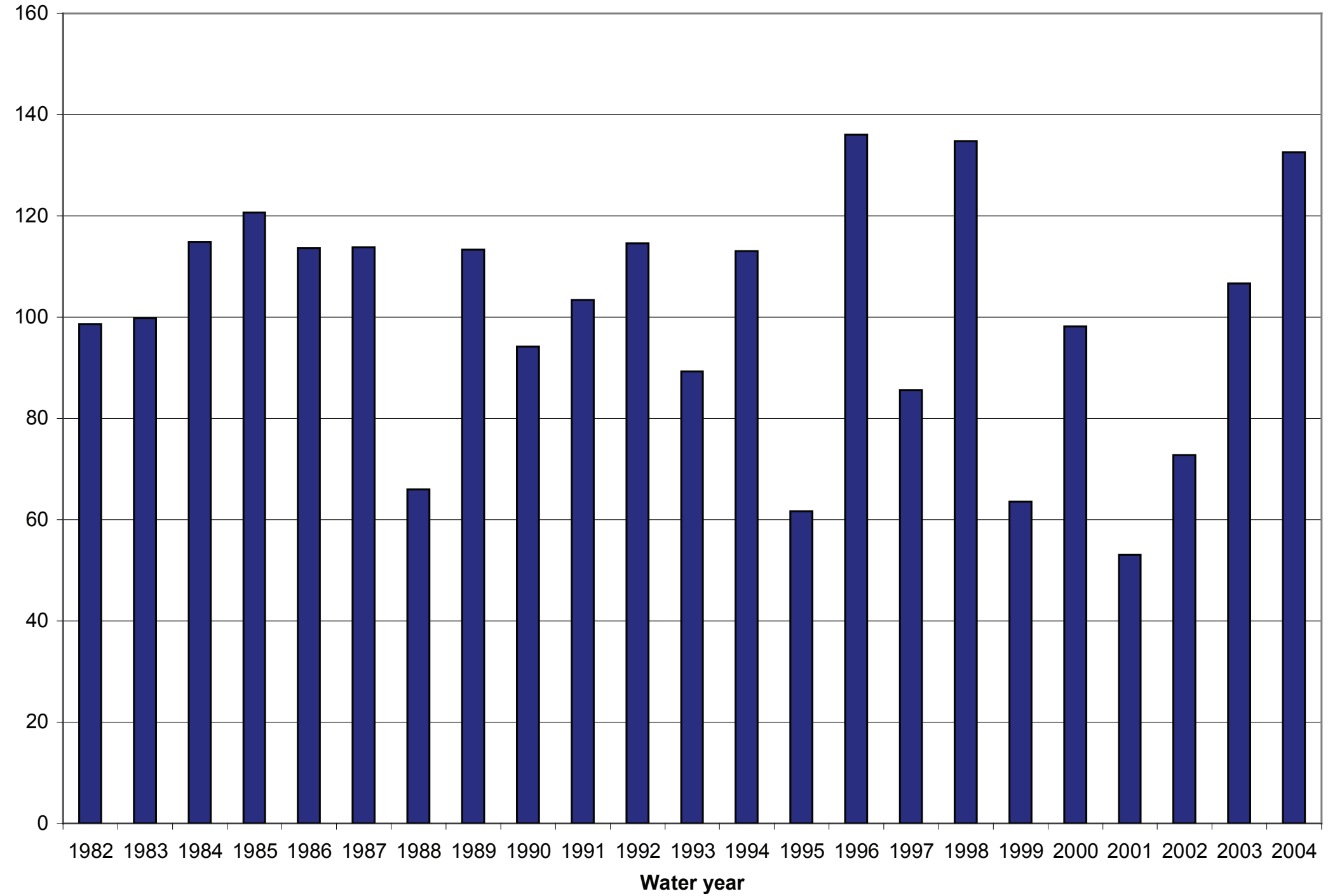

Figure 3. Percentage of average precipitation measured at Lemon Dam for the period of October 1 - April 30 of water years $1982-2005$. Climate data obtained from the Western Regional Climate Center, Desert Research Institute. 


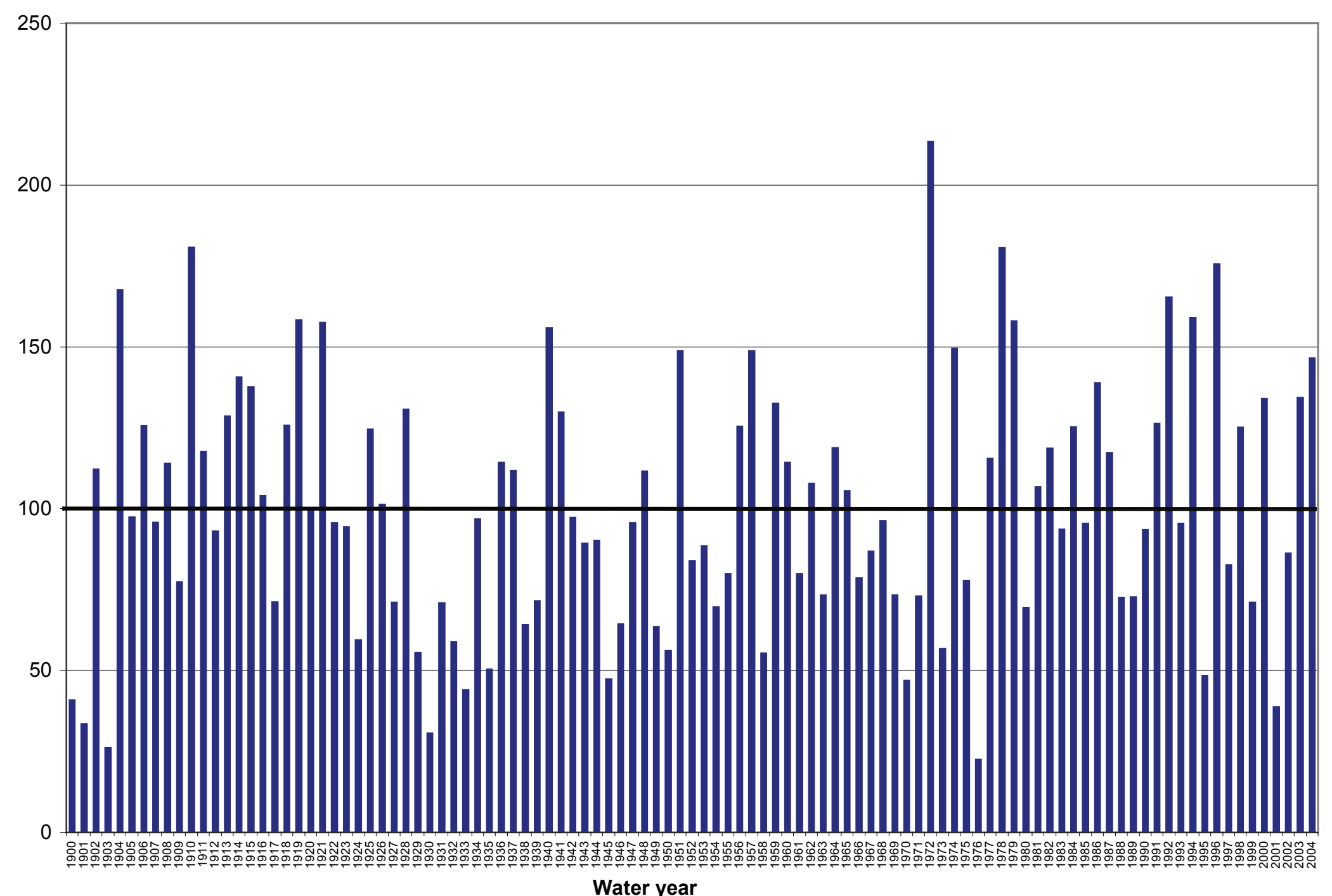

Figure 4. Percentage of average precipitation measured at Durango for the period of October 1-April 30 of water years $1900-2004$. Climate data obtained from the Western Regional Climate Center, Desert Research Institute. 


\section{Assessment Methods}

We used several approaches to assess the landslide complex, including evaluation of aerial photographs and geologic maps and reports, geologic mapping, subsurface exploration, laboratory testing, monitoring, and evaluation of climate data.

\section{Mapping}

We mapped geologic and hydrologic features in the landslide area in several stages, most of which were assisted by global positioning system (GPS) surveying and a GIS. La Plata County GIS personnel provided us with georeferenced, orthorectified aerial photography and topographic data that we used to produce base maps. Digital aerial photography provided by the county was taken during 2003 with a pixel size of $0.3 \mathrm{~m}$, and again during 2005 with a pixel size of $1 \mathrm{~m}$. We also examined, on loan from Fort Lewis College, 1:20,000scale U.S. Department of Agriculture aerial photographs taken on August 18, 1966 (EHW-3GG-14, 15, 83, 84). We digitized and orthorectified these photographs with a pixel size of $0.21 \mathrm{~m}$ using a GIS. Topographic data provided by the county were in the form of a 1.5-m contour-interval digital line graph produced using stereoscopic aerial photographs. We used these data in a GIS to produce a digital elevation model (DEM) of the ground surface. We produced derivatives of the DEM for use in our analyses, such as a slope map, shaded relief maps, and a 5-m contour-interval topographic map. The data provided and used by La Plata County are in the Colorado State Plane Southern Zone, US Foot projection using the North American Datum of 1983 (NAD 83), thus our work also uses this projection.

Initial mapping was performed on base maps produced from points surveyed using a recreational grade, Wide Area Augmentation System (WAAS) enabled GPS receiver, and the topographic and photographic data provided by La Plata County. We surveyed points of interest using the GPS receiver and combined them with topographic data in a GIS to produce a base map on which features of interest were then added by hand. The completed map was scanned then rectified and digitized in a GIS. Later mapping used the same topographic and photographic data, but surveying was performed using real-time differentially corrected GPS equipment (Pathfinder ProXT receiver and GeoBeacon manufactured by Trimble Navigation Limited) operated through a GIS on a rugged tablet computer (iXC2V manufactured by Xplore Technologies). This mapping system enabled us to directly map into the GIS while in the field. The majority of our field mapping was performed during early May 2005, with additional mapping performed at various times during the summer of 2005 and the spring and summer of 2006.

\section{Subsurface Exploration}

We investigated shallow geologic conditions of the landslide complex using hand-augered borings and hand-dug pits.
Using a 7.6-cm-diameter bucket auger, several borings were augered to a maximum depth of $1.8 \mathrm{~m}$ where auger refusal was encountered, likely on bedrock. Two borings were augered at the locations of P-1 and P-2 (pl. 1). Several pits were excavated by hand (with pick and shovel) near exploration pit EP-1 (pl. 1), although only EP-1 reached a depth greater than a meter due to encountering very large boulders. EP-1 was excavated to a depth of $1.6 \mathrm{~m}$. Soil samples were obtained from various depths within EP-1 for radiocarbon dating.

In addition to this subsurface exploration, we obtained reports for 10 water wells previously constructed along the Florida River valley floor near the landslide complex (locations of seven of the wells are shown on pl. 1). These reports were obtained from the State of Colorado Division of Water Resources and included information regarding depth of unconsolidated soil and underlying bedrock. The maximum recorded depth explored during construction of these wells was about 76 $\mathrm{m}(250 \mathrm{ft})$.

\section{Radiocarbon Dating}

Two charcoal samples obtained from pit EP-1 at depths of $1.6 \mathrm{~m}$ and $1.3 \mathrm{~m}$ in the older landslide deposit were prepared and submitted for radiocarbon dating $\left({ }^{14} \mathrm{C}\right.$ dating $)$. Preparation included removing the core of the charcoal and washing it several times in deionized water. The samples were sealed and submitted for testing at the National Ocean Sciences Accelerator Mass Spectrometry Facility at Woods Hole Oceanographic Institution. ${ }^{14} \mathrm{C}$ dates were converted to calibrated calendar years using CALIB (Stuiver and Reimer, 1993).

\section{Monitoring}

We established systems during May 2005 to monitor localized surface displacement and shallow ground-water conditions within the landslide complex in near-real time. These systems are operated by a field computer/datalogger. We also established survey monuments across the landslide complex that can be re-surveyed on an episodic basis.

\section{Near-real-time Monitoring Operation and Data Transfer}

Instrumentation installed on the landslide complex included six extensometers consisting of cable-extension transducers (CETs), mounts, and anchors to monitor possible ground surface displacements, and two vibrating-wire piezometers to monitor shallow ground-water pressures. Data from these instruments are recorded at the site by a Campbell Scientific CR10x datalogger equipped with a digital cellular modem for remote communication. Data retrieval is accomplished via the public cellular telephone network. The locations of the instruments and datalogger are shown on plate 1 . The datalogger powers and scans the instruments and records instrument output on a user-defined schedule. We have generally recorded 
instrument readings on a 10-minute schedule. Power to operate the datalogger and instruments is provided by a 12 -volt battery that is charged by a voltage-regulated solar panel.

Data from the site are retrieved automatically from the datalogger by computer dial-up via cellular telecommunications using Campbell Scientific LoggerNet ${ }^{\mathrm{TM}}$ software running on a computer located at the USGS offices in Golden, Colorado. The data are automatically retrieved on a daily schedule, although the data retrieval interval can be adjusted by the user. Data can also be retrieved at any time by manually initiating the communication link through the LoggerNet ${ }^{\mathrm{TM}}$ software. In addition, the datalogger that controls operation parameters for the monitoring devices can be modified at any time through the communication link.

\section{Surface Displacement Monitoring}

The extensometers are used to detect and monitor possible surface deformation at six locations within the landslide complex (pl. 1). Four of the CETs were manufactured by Celesco Transducer Products, Inc., and two were manufactured by Psi-Tronix, Inc. Extensometers C-1 and C-6 are deployed across the apparent headscarp (the steep slope created upslope of a landslide as it moves) of the older bedrock landslide, and extensometers C-2 through C-5 were deployed in areas identified as potentially active based on the presence of recent fracturing or other surface features that suggested recent landslide activity. Extensometers C-1, $\mathrm{C}-3$, and C-4 have a total range of $150 \mathrm{~cm}$, extensometers $\mathrm{C}$ 2 and C-5 have a $380 \mathrm{~cm}$ range, an d extensometer C-6 has a $760 \mathrm{~cm}$ range. As configured with the datalogger, the resolution of the 150,380 , and $760 \mathrm{~cm}$ range extensometers is $0.04 \mathrm{~cm}, 0.10 \mathrm{~cm}$, and $0.20 \mathrm{~cm}$, respectively. Extensometer C-3 malfunctioned upon installation and corrupted readings for C-1 and C-2 until it was replaced on June 22, 2005.

The extensometers measure displacement by means of a small-diameter cable that extends from the fixed instrument to a fixed anchor point. Therefore, it was necessary to protect the extension cable from disturbance and entanglement by wildlife. This was accomplished by mounting the instruments and anchor points on telescoping steel fence posts at a height sufficient to allow deer or elk to pass under the cable. In most cases, this resulted in the extension cable being at a height of about three meters or more above the ground surface. While necessary to protect the extension cables from wildlife, this method of mounting the extensometers unavoidably introduced the possibility of greater noise in the measurements from other environmental factors. Any tilting or wobbling of the fence posts would result in apparent movement. In addition, because the extension cable is exposed, the instrument readings are subject to noise caused by wind, rain, ice, and snow loading on the cables. Therefore, interpretation of changes in extensometer readings requires careful evaluation of weather conditions at the time of the reading changes. Typically, adverse weather conditions result in abrupt, temporary changes in readings rather than gradual, permanent changes that would be expected from landslide reactivation.

Wind-blown deadfall from burned trees impacted extensometer cables six times during fall 2005 through spring 2006. These occurrences caused displacement in extensometer readings that was rapid and of significant, but finite, distance. This displacement pattern suggested deadfall or equipment malfunction. USGS scientists or J. Ey (FWCD) evaluated each of these occurrences and removed extension cables from beneath deadfall, removed hanging branches from extension cables, and reset the extensometers. We experimented with installation of extension cables through flexible metal conduit run along the ground (C-2 and C-3) to address the deadfall issue. Deadfall occurred on the conduit-encased extension cables and did not result in problems. However, ice formed within the conduit during the winter and caused displacement of both CETs and cable breakage at C-3. This cable was repaired on April 9, 2006.

Long signal cable runs, necessary to connect the widely spaced extensometers to the datalogger, created additional problems. These long runs resulted in electrical noise appearing in extensometer readings. In addition, unprotected signal cables were subject to damage from rodents chewing through the cable insulation. Rodent damage was experienced on some of the signal cables after installation; the signal cable from C-5 was fully severed by rodents within a few days of installation. The cable was repaired on June 22, 2005. The signal cables from extensometers C-1, C-2, C-3, and C-6 were subsequently run through flexible metal conduit. Extensometers C-4 and C-5 should be relocated and equipped with remote power and dataloggers (see below); hence, their signal cables were not run through metal conduit.

\section{Shallow Ground-water Monitoring}

Vibrating-wire piezometers manufactured by Slope Indicator, Inc. were installed at two locations, P-1 and P-2, within one of the active areas of the landslide complex (pl. 1). The vibrating-wire piezometers have a range of $345 \mathrm{kPa}$ (50 psi), and a manufacturer's stated accuracy and resolution of \pm 0.1 percent and 0.025 percent of full-scale, respectively. The piezometers are also equipped with built-in thermistors for monitoring ground-water temperature, or soil temperature in the absence of ground water. Piezometer 2 malfunctioned upon installation and was replaced on November 16, 2005. The piezometers were installed just above the contact between colluvium and bedrock in hand-augered holes. This contact was generally at a depth of about $1.5 \mathrm{~m}$. No standing ground water was encountered in the augered holes at the time of instrument installation, and the holes were backfilled with compacted colluvium. The drilling and piezometer installation process disturbed ground-water conditions at the piezometer locations for several days to weeks. This disturbance and observed drying of colluvium that was already occurring resulted in the piezometers not detecting ground water during spring 2005. 


\section{Episodic Displacement Monitoring}

\author{
Installation and Distribution of Monitoring Points
}

During September 2005, 14 monitoring points were installed on the landslide complex, and one was installed about $800 \mathrm{~m}$ east of the complex to provide survey control (pl. 1, eastern control monument is outside of the area shown on the plate). Each monitoring point consists of a $60-\mathrm{cm}-1$ long mason spike driven so that about $3-6 \mathrm{~cm}$ of the spike protrudes above the ground surface. The top of each spike was fitted with a stamped aluminum cap. We attempted to evenly distribute the points on the landslide complex, while also maintaining a clear view to the sky (including broad horizon view) from each point. A clear view to the sky is necessary for reliable acquisition of GPS signals. We utilized GPS for surveying the monuments, although they could also be surveyed using a theodolite or other techniques. It was quite difficult to install all monuments on the landslide complex with a clear view to the sky because of the steep slope and variable tree cover. Because of these problems, long field occupations (greater than one hour) were required while GPS surveying some of the monitoring points.

\section{GPS Background and Field Work}

GPS has been previously described (for example, Leick, 1990; Van Sickle, 1996) and application of GPS to landslide assessment has also been described elsewhere (for example, Jackson and others, 1996; Gili and others, 2000; Malet and others, 2002; Coe and others, 2003). Therefore, we only briefly describe the equipment, methods, and processing techniques used at the Florida River landslide complex.

All monitoring points were surveyed using Ashtech Z12 and Z-Surveyor, dual-frequency receivers equipped with Ashtech geodetic or marine antennas. Rapid-static or static GPS surveying with positioning relative to a base station with known location was used for all points. We used three receivers for the September 2005 survey; one receiver was positioned at a reference base station (CP1), and two receivers roved to points on the landslide complex. Like the monitoring points, base station $\mathrm{CP} 1$ consists of a mason spike and a stamped aluminum cap. The coordinate position of CP1 was determined by a static-GPS survey on September 27, 2005 using a USBR Control Station (Station Designation RTAB, located near the west abutment of Lemon Dam about $2 \mathrm{~km}$ northwest of the landslide complex) as a reference base station. The monitoring points have been surveyed only once so they have yet to provide data regarding ground displacement.

\section{GPS Post-processing}

All GPS data were processed using Ashtech Precise Navigation (PNAV) software, v. 2.4.00M. Baselines and point positions were calculated relative to $\mathrm{CP} 1$ for each of the measured monitoring points. Baselines were all less than $2 \mathrm{~km}$ long; thus, we did not remove ionosphere delay of the GPS signal as part of the processing. Standard errors of computed point positions were derived from PNAV and were less than $1.5 \mathrm{~cm}$ in horizontal and $2.5 \mathrm{~cm}$ in vertical.

After processing, coordinate positions for all measured points were transformed into the North American Datum of 1983 and then projected into the Colorado State Plane, Southern Zone, coordinate system using Ashtech's PRISM software. Ellipsoid heights were transformed into heights in the North American Vertical Datum of 1988 using PRISM software and the GEOID96 model provided by the U.S. National Geodetic Survey. Coordinates and standard errors of monitoring points are presented in table 1 .

\section{Observations}

Landslides within the Florida River landslide complex range from active shallow landslides in colluvium to dormant deep landslides primarily in bedrock. The activity levels of the landslides appear to be highly dependent on short- to longterm climatic conditions.

\section{Climate}

Landslide activity observed during April and May 2005 correlated temporally with rapid melting of a deep, wet snow pack. Figure 5 shows Lemon Dam climate data for water year 2004, which includes the April and May 2005 period of landslide activity. The amount of water accumulated as snowfall can be estimated for a given period by subtracting the cumulative precipitation value corresponding to the beginning of the period (fig. 5) from the value corresponding to the end of the period, assuming that no snowmelt occurred during the period. Using this method, over $44 \mathrm{~cm}$ of water accumulated as snow by the time the snow pack began its final melt off on February 20 (fig. 5). About seven additional centimeters of precipitation fell as snow during the last two weeks of March. The snow pack completely melted by April 13 .

Figure 6 shows precipitation data for water year 1983, which, by comparison with the other water years during the period of record (fig. 3, 1982-2005), approximately represents average conditions through April. During this typical year, about $29 \mathrm{~cm}$ of precipitation fell as snow by the time the snow pack began its final melt off beginning in the middle of February, compared to over $44 \mathrm{~cm}$ that fell during this period of water year 2004. Final melting of the snow pack during water year 1983 occurred gradually from the middle of February through the end of March (fig. 6).

Water year 2004 was significant because of the relatively great amount of water released by snowmelt over a relatively short time; however, other years during recent history have been similar. For example, a total of about $48 \mathrm{~cm}$ of water was released from snow during the water year 1992 snowmelt period of late February through mid-April (fig. 7), which results in a snowmelt intensity similar to that of water year 2004. In contrast, water year 2005 experienced below-average precipitation and relatively insignificant snowmelt (fig. 2). 
Table 1. Survey monument coordinates and standard GPS error ${ }^{1}$.

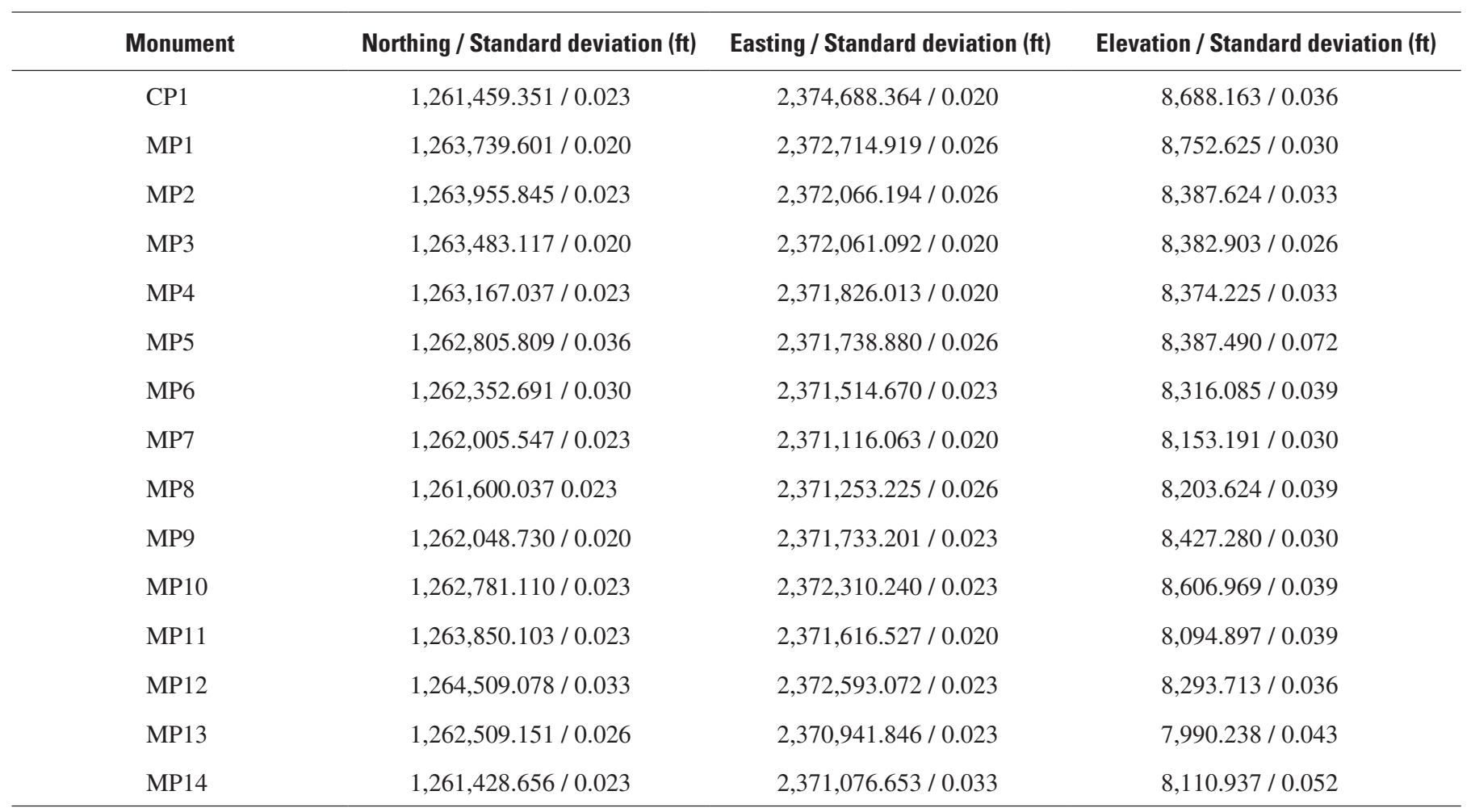

${ }^{1}$ Coordinates are in NAD 83, Colorado State Plane Southern Zone, US foot projection

Through April 30 of water year 2005, 74 percent of average precipitation had fallen and only $8 \mathrm{~cm}$ of precipitation was released during final spring snowmelt.

\section{Bedrock}

Bedrock units are exposed in several locations within the landslide complex. Bedrock displaced by landslide movement is properly called landslide debris but will be referred to herein as bedrock for simplicity and clarity. Bedrock units evaluated in and near the landslide complex are typically white to tan to gray sandstone with minor amounts of greenish gray and grayish red shale and variably colored conglomerate. Bedrock units shown on plate 1 are those of Carroll and others (1997).

Sandstone evaluated both within and outside of the landslide is generally moderately strong to strong, hard to very hard, and little to moderately weathered (Naval Facilities Engineering Command, 1986). There are a few beds of sandstone that are weak and friable, but these are of limited extent. Sandstone beds are usually little fractured (0.3-1 m fracture spacing) to massive ( $>1 \mathrm{~m}$ fracture spacing). Shale beds observed intermittently in an 85-m-thick bedrock exposure are typically less than a meter thick and spaced several to tens of meters apart. Shale is generally friable to weak, of friable to low hardness, little to moderately weathered, and closely fractured (0.03-0.15 $\mathrm{m}$ fracture spacing) to crushed ( $<0.03 \mathrm{~m}$ fracture spacing).

Bedding orientations are quite similar both within and outside the older landslide, with strike generally east-west and dip to the south between 9 and $16^{\circ}$. Bedding orientation in the plane of section is indicated on the geologic cross sections (pl. 1) whereas bed thicknesses are exaggerated on the cross sections; bedding shown on the cross sections is meant to only represent bedding orientation.

Two generally consistent fracture sets were observed within all bedrock units near and within the older landslide ( $\mathrm{pl}$. 1). As with bedding planes represented on the geologic cross sections, fractures shown on the cross sections represent fracture orientation in the plane of section but not fracture spacing. The more pervasive fracture set generally strikes northwestsoutheast and dips between $68^{\circ}$ to the south and $85^{\circ}$ to the north. The other fracture set has generally northeast-southwest strike and vertical dip. Fracture spacing ranges from about a centimeter within shale beds to greater than one meter within well-indurated sandstone beds. Most fractures are closed and filled with up to about one centimeter of deeply weathered rock. Several fractures were observed to be open up to about five centimeters. Open fractures were generally observed in larger outcrops and near the slope face. 


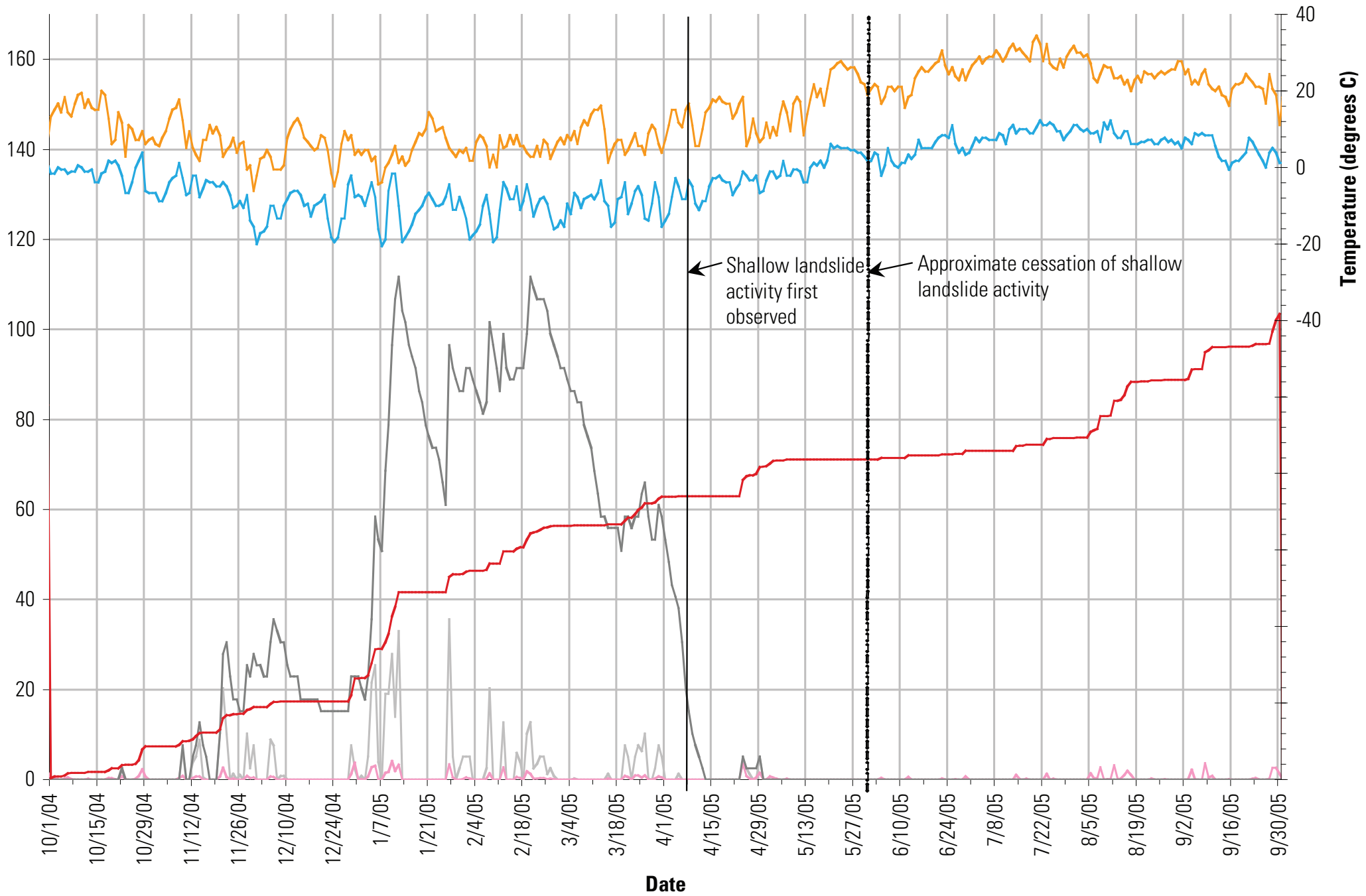

Figure 5. Climate data measured at Lemon Dam, October 1, 2004 - September 30, 2005. Data obtained from the Western Regional Climate Center, Desert Research Institute. 
$\longrightarrow$ Snow fall $\longrightarrow$ Daily precipitation $—$ Snow depth $—$ Cumulative precipitation $—$ Minimum temperature $—$ Maximum temperature

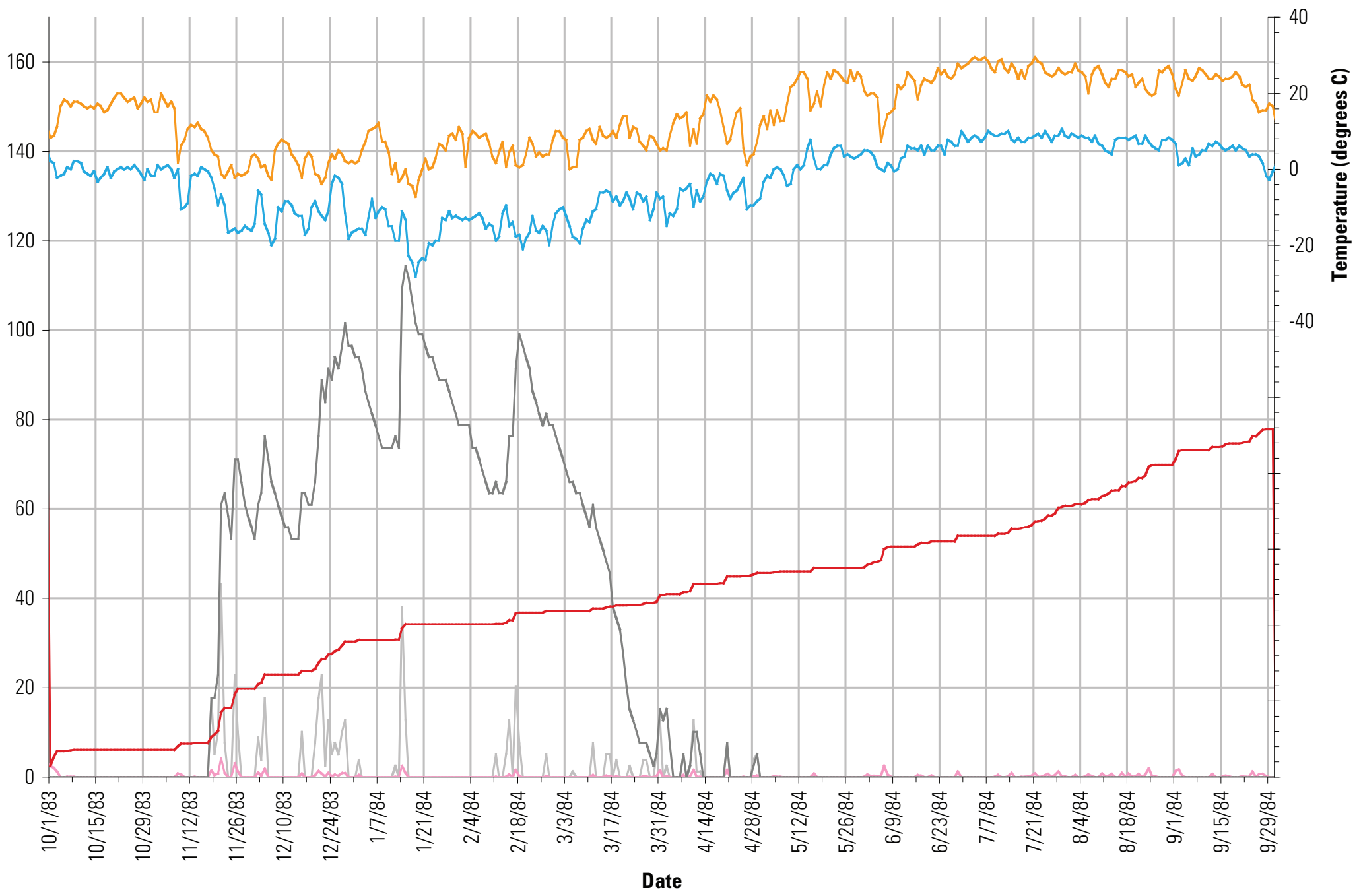

Figure 6. Climate data measured at Lemon Dam, October 1, 1983 - September 30, 1984. Data obtained from the Western Regional Climate Center, Desert Research Institute. 
— Snow fall —- Daily precipitation — Snow depth —Cumulative precipitation —- Minimum temperature —— Maximum temperature

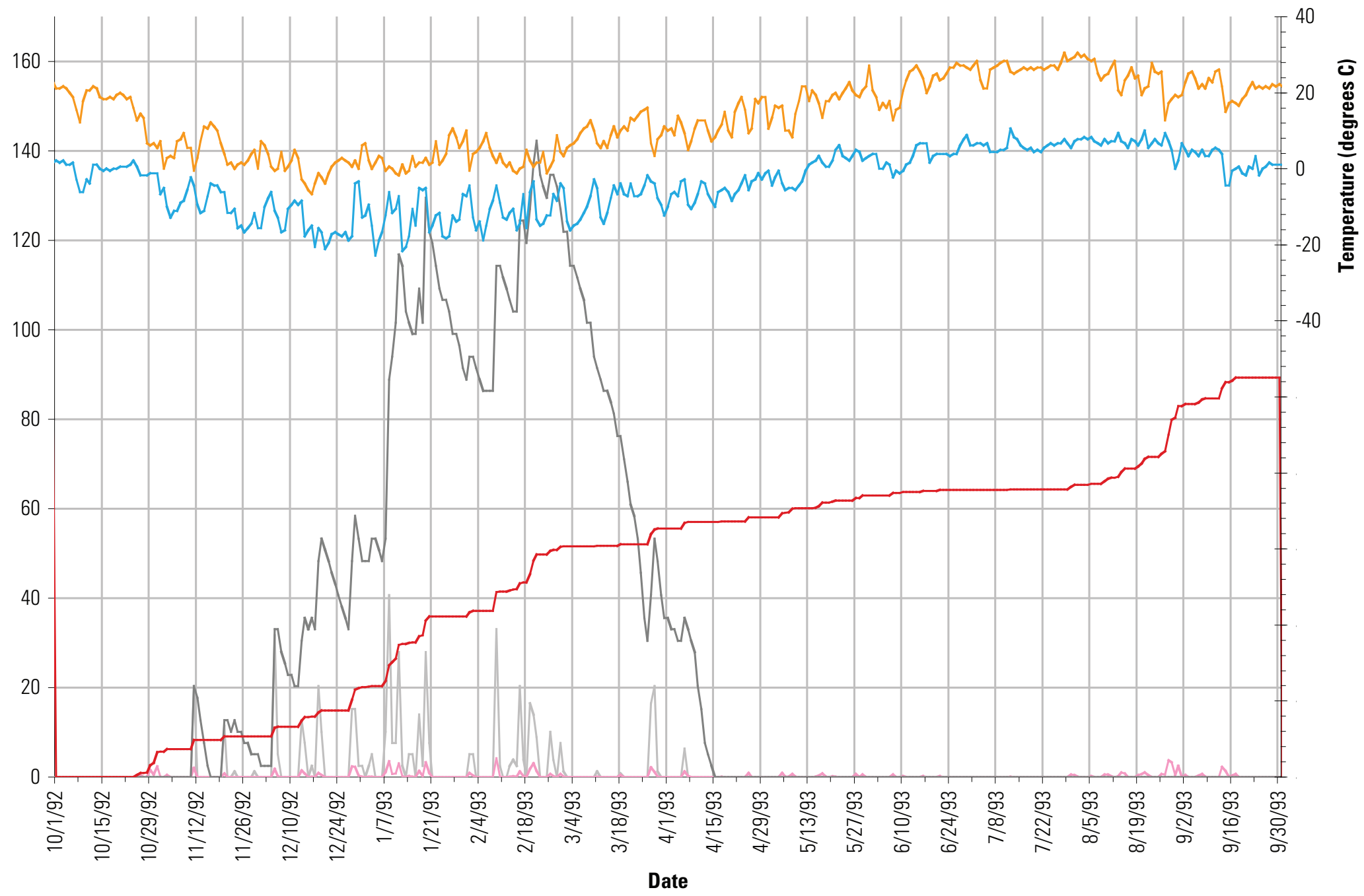

Figure 7. Climate data measured at Lemon Dam, October 1, 1992 - September 30, 1993. Data obtained from the Western Regional Climate Center, Desert Research Institute. 


\section{Surficial Deposits}

Surficial deposits were observed and evaluated at the ground surface, in exposures created by recent landslide activity, within exploratory pits, as samples obtained from hand-augered boreholes, and in logs of water wells constructed by others along the Florida River valley floor.

\section{Alluvium}

Surface exposures and well records indicate that alluvium in the Florida River valley consists mainly of boulders and gravel with some sand. Earlier water-well drilling encountered alluvium to depths of 6-24 m, below which bedrock was encountered. The depths of alluvium observed during waterwell construction are consistent with those shown on cross section A-A' (pl. 1).

\section{Colluvium}

As with bedrock descriptions, colluvium displaced by landslide activity is properly called landslide debris but will be referred to herein as colluvium for clarity and simplicity. Most of the slope on which the landslide complex occurs is mantled by colluvium (pl. 1). The colluvium exposed in cavities created by recent landslides and during our subsurface explorations is generally $2 \mathrm{~m}$ deep and consists of clayey, silty sand with little gravel and boulders (American Society for Testing and Materials, 2002, test method ASTM-D2488). In a few areas, boulder content in the colluvium is probably as high as 80 percent. Colluvium is generally less than about a meter thick along the older landslide headscarp (pl. 1). In general, the colluvium is loose to medium dense with moderately plastic fines (silt and clay). About 10 percent of the boulders observed within colluvium inside of the landslide complex are slickensided; they have polished and striated surfaces that resulted from friction along a fault plane (Bates and Jackson, 1987).

During the summers of 2005 and 2006, colluvium was generally observed to be moist; however, in spring 2005 it was generally wet to saturated at the ground surface and to its full depth (where exposed). Ground water appeared to be perched within colluvium on underlying bedrock. The saturated to wet condition of most colluvium extended into June 2005 and was observed in a few isolated locations throughout summer 2005 and during May 2006. The most significant concentration of surface water and ground water within colluvium, based on observations made at the ground surface, occurred around the easternmost active landslide (pl. 1). Sources of surface water were generally snowmelt, broad ground-water seepage zones, springs from the walls of cavities created by recent landslide movement, and springs from the toes (downslope ends) of recent landslides. In addition, a significant artesian spring was observed issuing from sandstone bedrock upslope from the easternmost landslide (immediately downslope of "datalogger", pl. 1). Discharge from this spring was as high as approximately $110 \mathrm{~m}^{3} / \mathrm{d}$, with observed flow highest during late April
2005 and decreasing consistently until it ceased in June 2005. The flow from this spring ponded on the south end of the large topographic bench located immediately downslope (pl. 1).

The spring and ponding on this bench probably contributed to the greater apparent saturation observed in colluvium located downslope, such as at the easternmost active landslide. In contrast, the spring was observed to be inactive during and soon after spring 2006 snowmelt.

\section{Shallow Landslides}

We identified and mapped the complete boundaries of 19 shallow landslides and the headscarps of two additional shallow landslides within the Florida River landslide complex, all of which appeared to be active during spring 2005 (pl. 1). Three of these active landslides are located along the southern part of the older landslide headscarp (pl. 1) while the other 18 are located within the body of the older landslide. Other small landslides may be located along the steep southern part of the headscarp of the older landslide but were not visible on aerial photographs or during limited field study; field study was limited in this area due to the steep slope and an abundance of vertical and overhanging loose rock. Mapped active landslides are either translational landslides that moved less than a few meters along discrete shear surfaces (nine landslides) or ground failures that essentially liquefied during translation and mobilized as debris flows that moved between 12-250 m downslope (12 landslides) (pl. 1).

Active translational landslides were identified from headscarps along landslide heads (upslope ends), thrust faults along landslide toes (downslope ends), and pressure ridges, pull-apart basins, and lateral displacement along landslide margins. Debris flows were identified from the cavities they created and flow deposits located downslope. Figures 8-10 show features of some of the translational landslides, while figures 11-12 show some of the debris-flow features. Nine debris flows mobilized from within translational landslides, whereas three landslides completely mobilized as debris flows (pl. 1). Based on surface morphology of active landslides and the subsurface exposures they created, it appears that the landslides generally involved the full depth of colluvium and slid along the contact between colluvium and bedrock, which is generally at a depth of about two meters. Debris-flow volumes range between $150-1,500 \mathrm{~m}^{3}$, whereas translational-landslide volumes range between 2,000-35,000 $\mathrm{m}^{3}$.

Movement of the active landslides was first observed by area residents on April 8, 2005 (M. Radosevich, pers. commun., 2005). Landslide activity appeared to continue sporadically into late May 2005. Our observations and those of area residents suggest that colluvium involved in the landslides was mostly to entirely saturated at the time the landslides initiated, presumably by infiltration of snowmelt. Figure 13, which presents climate data from Lemon Dam for the period of February 20-April 16, 2005, shows that snowmelt preceded landslide activity and was nearly complete when landslides were first observed on April 8. Measurable landslide activity appears to 
have stopped by the time our extensometers began obtaining reliable readings on June 22, 2005, and no landslide displacement has been detected by the extensometers as of July 14, 2006 (fig. 14). Apparent displacements suggested by extensometer reading changes shown on figure 14 are due to several factors. Extensometer reading fluctuations of a few centimeters or less are generally due to diurnal atmospheric fluctuation. Apparently instantaneous, large displacements suggested by the extensometers on figure 14 are either due to tree fall across extension cables and repair of such damage, or are false displacements due to long signal cable runs, rodent damage to signal cables, or atmospheric conditions. Gradual displacement measured by C-2 and C-3 during fall 2005 and winter 2005/06 was apparently due to formation of ice around extension cables that were encased within flexible metal conduit.

Ground-water conditions detected by our piezometers within the easternmost active landslide are shown on figure 15 . The pressure head results shown on the figure have been modified from instrument output to account for instrument elevation and temperature. Expressed as pressure head and considering the installation method of the piezometers, the pressure head results (fig. 15) are approximately equivalent to the saturated thickness of the colluvium at the piezometer locations. The piezometers indicated an absence of ground water within colluvium until March 6, 2006. The head fluctuation, generally from -0.1 to 0.1 prior to March 2006, appears to correlate with atmospheric pressure fluctuations measured at the Durango - La Plata County Airport. The increases in pressure head first to $0.4 \mathrm{~m}$ measured by P-1 on March 6, 2006, and then to 1.0-1.1 measured by both piezometers during the first week of April 2006 follow a period of warming in late February and then steady warming in mid-March that resulted in snowmelt. The February snowmelt released about $8 \mathrm{~cm}$ of water and the March snowmelt released about $11 \mathrm{~cm}$ of water.

In addition to the shallow landslides described above, we observed a few isolated rockfalls along the southern part of the older landslide headscarp. These rockfalls had volumes of less than a few cubic meters each and traveled only a few meters. The rockfalls appear to be of variable age; only one rockfall appeared to be recent and this is located at the head of an active shallow landslide located near the south end of the landslide complex.

\section{Deep Landslides}

The shallow landslides described above cover a significant part of the surface of the large older landslide that comprises the bulk of the Florida River landslide complex (pl. 1), but they only account for a very small part of its volume. Deep landslides (used here to refer to landslides that extend beneath colluvium into bedrock) have occurred within the landslide complex; the largest is the older landslide (pl. 1). This older landslide has a generally easily identifiable head due to the topographic bench it created, as illustrated by geologic cross

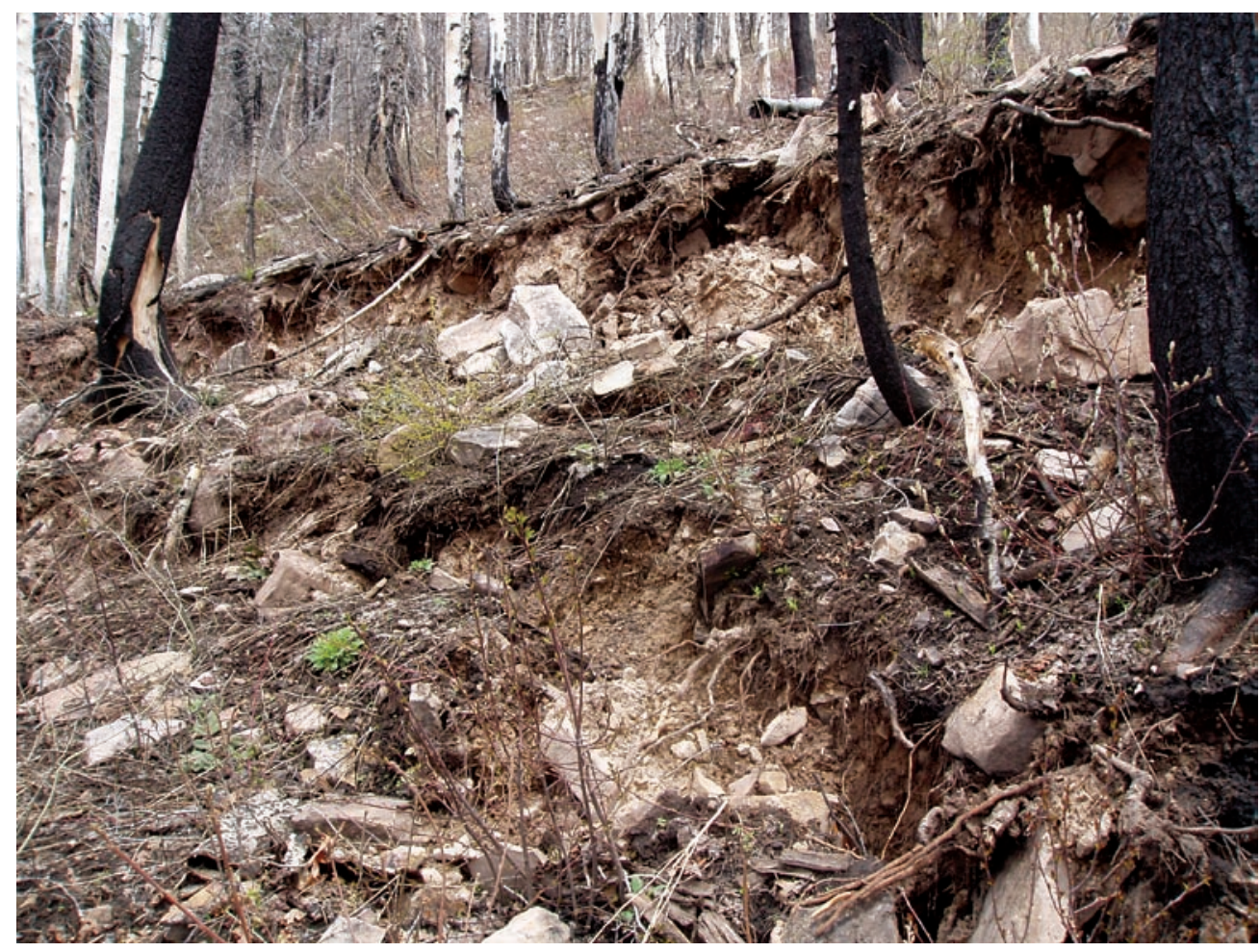

Figure 8. Head of a translational landslide that was active during spring 2005 within the Florida River landslide complex. Headscarp in upper part of photograph is $3.2 \mathrm{~m}$ high. 


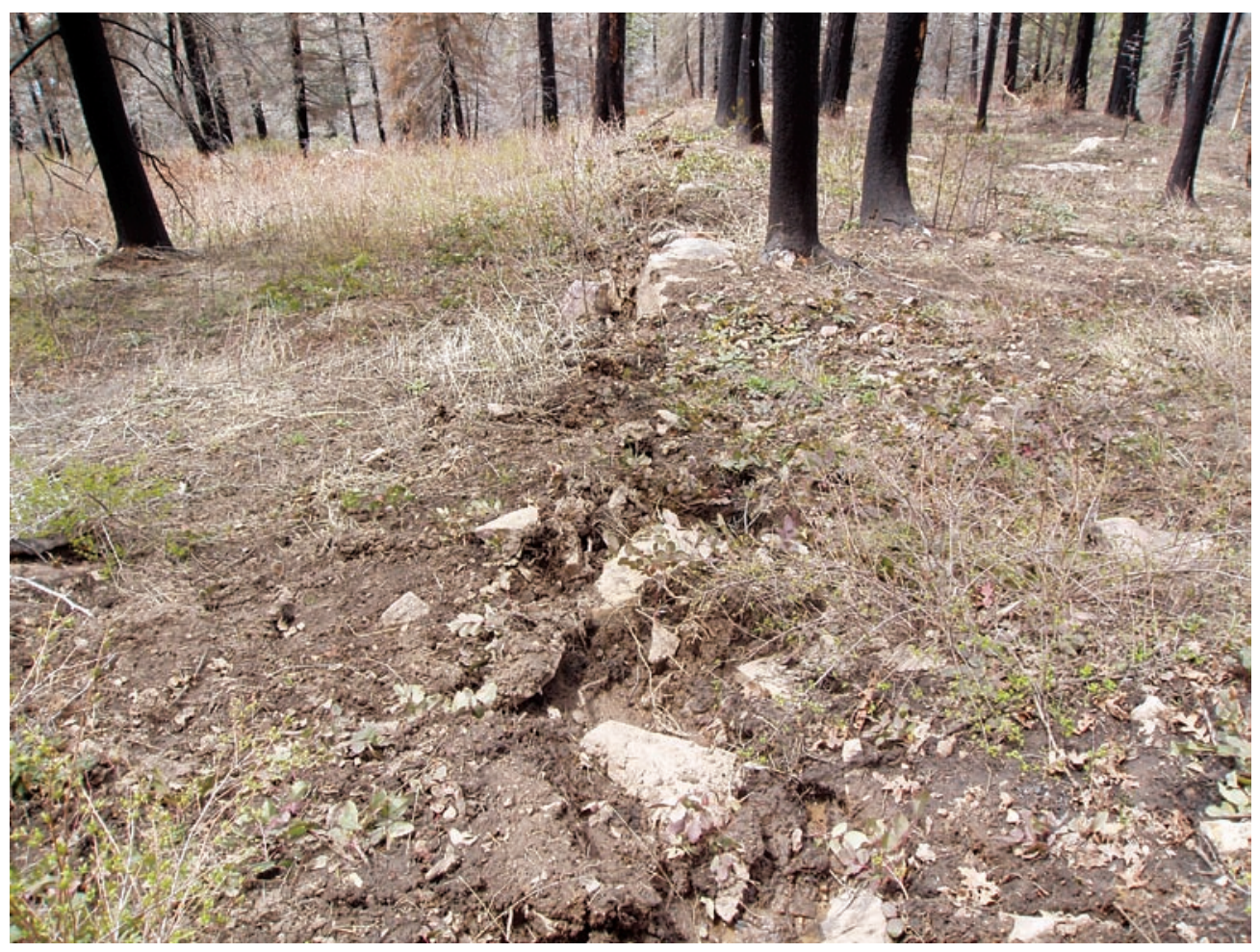

Figure 9. Lateral shear zone along the margin of a translational landslide that was active during spring 2005 within the Florida River landslide complex. Landslide is on the right side of the ground fracture. Trees along shear zone are about $0.3 \mathrm{~m}$ in diameter.

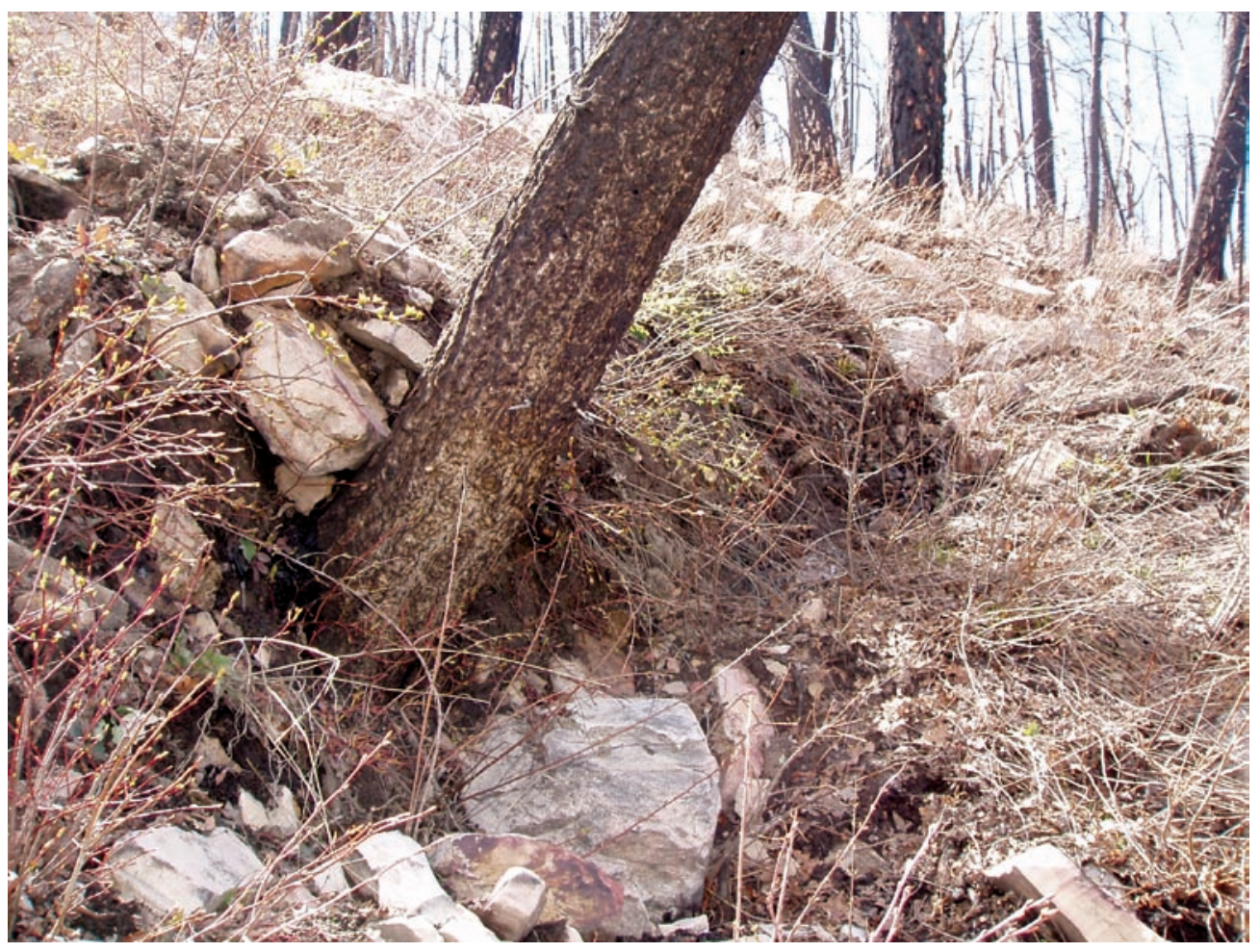

Figure 10. Toe of a translational landslide that was active during spring 2005 within the Florida River landslide complex. The toe is thrusting over the leaning tree that is about $0.4 \mathrm{~m}$ in diameter. 


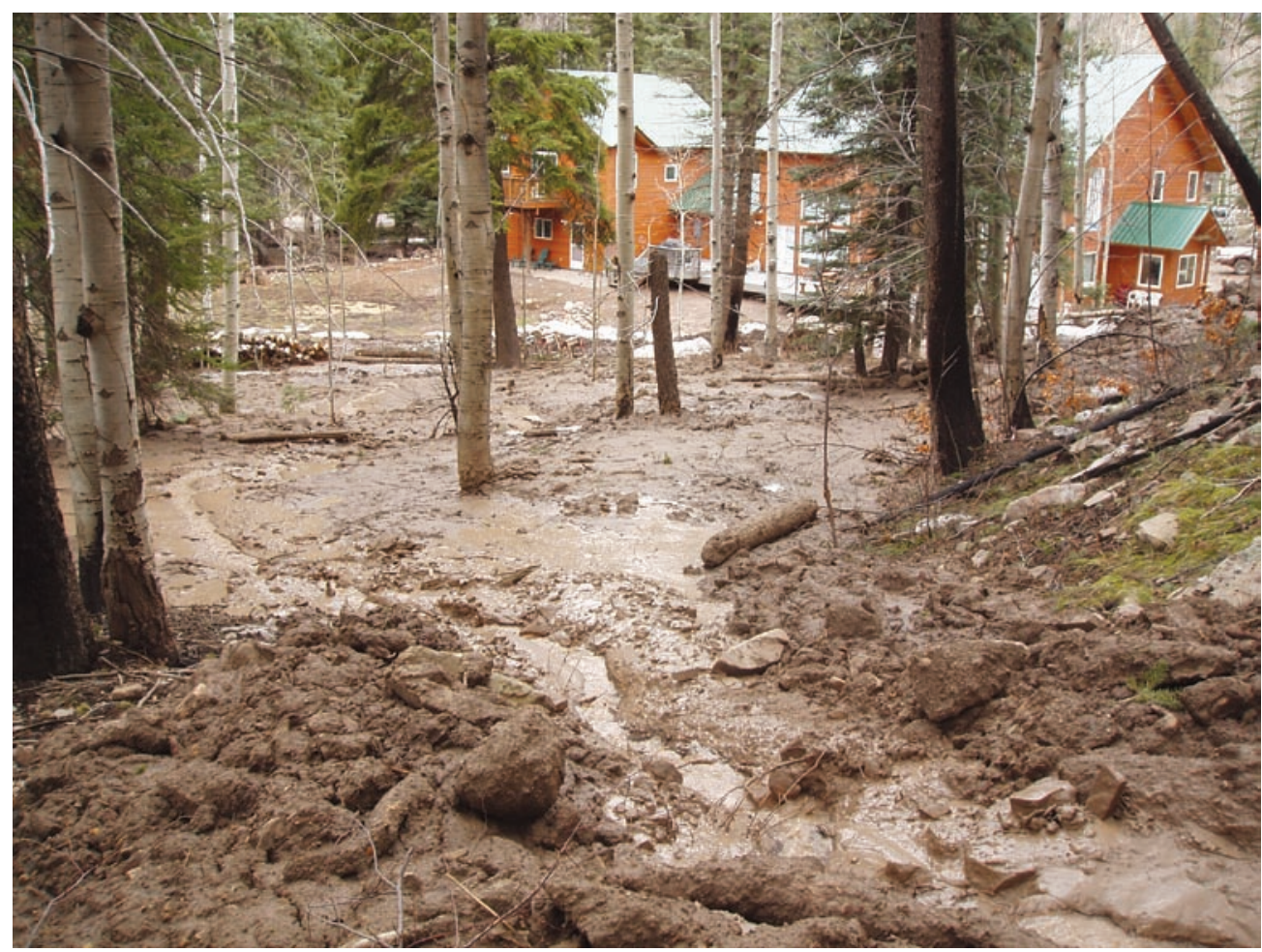

Figure 11. Deposit of a debris flow mobilized from a shallow landslide that was active during spring 2005 within the Florida River landslide complex.

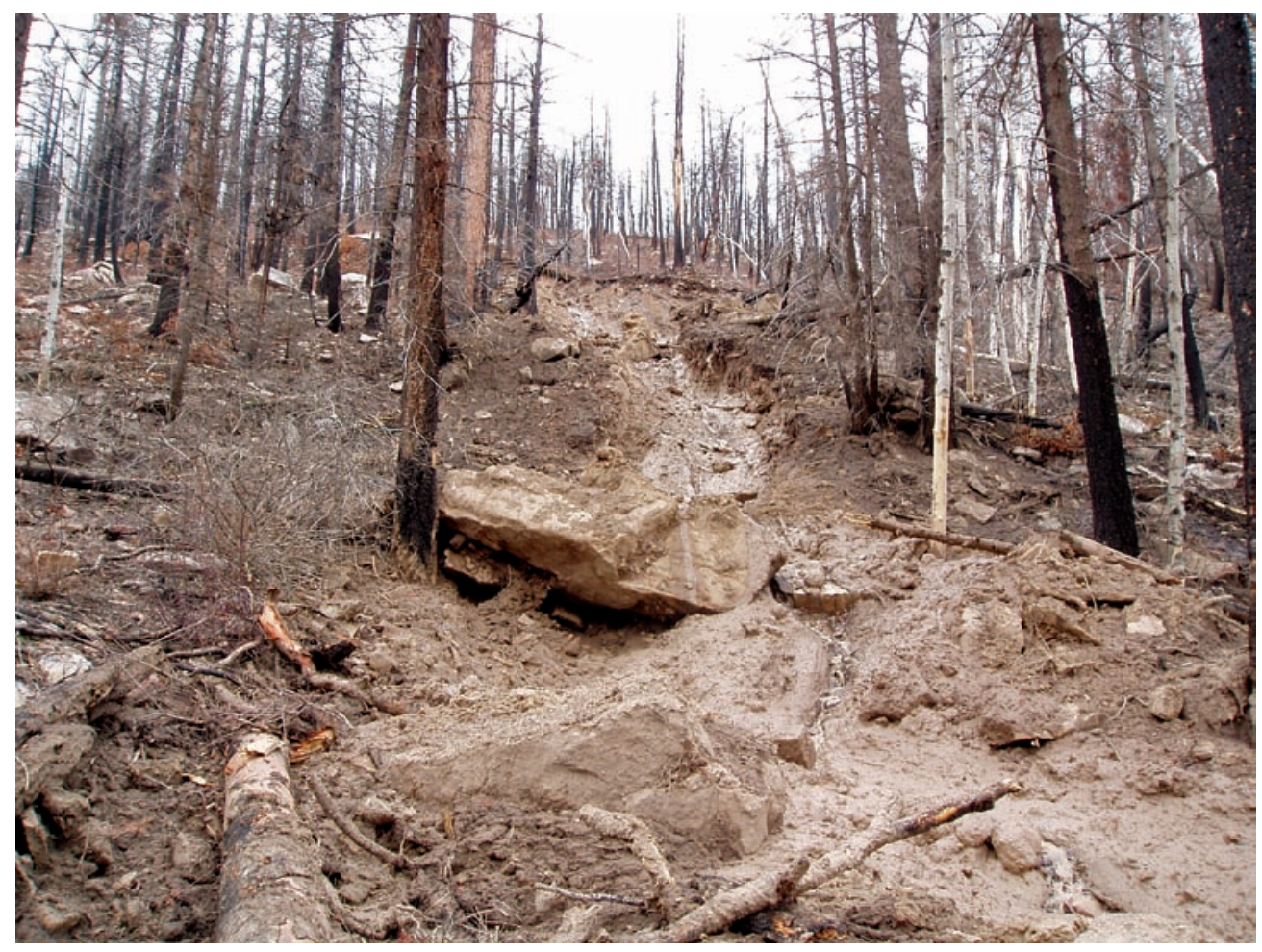

Figure 12. Source area, flow track, and part of a deposit of a debris flow mobilized from a shallow landslide that was active during spring 2005 within the Florida River landslide complex. Trees are 0.1-0.3 $\mathrm{m}$ in diameter. 
section A-A' (pl. 1) and figures 16-17. The older landslide essentially has no left margin (when viewed in downslope direction) as the landslide head and toe meet at an acute angle. The right margin is difficult to identify beyond the landslide head, which is not uncommon in the absence of geologic exposures or recent ground displacement. The older landslide toe was generally mapped at the slope toe, except where a colluvial apron apparently formed following landslide movement. The approximate subsurface geometry of the older landslide was estimated from morphologic conditions and by constructing 18 geologic cross sections (for example, cross sections A-A' and B-B', pl. 1). The landslide covers an area of 490,000 $\mathrm{m}^{2}$ and has an average thickness of $40 \mathrm{~m}$. Much of the central part of the older landslide is on the order of 50-70 m thick. The volume of the older landslide is $1.97 \times 10^{7} \mathrm{~m}^{3}$.

The morphology of the head and headscarp of the older landslide is very consistent along its length. The location of the older landslide head relative to the top of the headscarp indicates that the older landslide translated downslope approximately $150 \mathrm{~m}$ (measured horizontally) along a basal rupture zone or surface that approximately parallels the ground surface. The basal shear zone cuts across a 325-m section of bedrock (measured vertically, cross section A-A', pl. 1). This is somewhat unusual because landslides in bedrock often rupture along pre-existing planes of weakness, such as bedding planes (for example, most of the landslides mapped in the area by Blair, 1977 occur along bedding planes). The basal rupture of the older landslide within the Florida River landslide complex may have initially utilized fracture surfaces as planes of weakness, but still had to shear through presumably intact rock (cross sections A-A' and B-B', pl.1). The older landslide headscarp is generally inclined $31-37^{\circ}$ and is covered by slickensided boulders. These boulders were probably located within the basal shear zone of the landslide and were exposed by landslide displacement along the headscarp. The highest part of the head of the landslide deposit is the flattest and contains a few shallow closed depressions near EP-1 (pl. 1).

Rock exposed in the lower part of the older landslide and near its toe show characteristics consistent with outcrops located elsewhere within the landslide and outside its boundaries, suggesting that little rotation occurred during landslide displacement. Slope inclination near the landslide toe is slightly steeper than at mid-slope and colluvial aprons occur along the slope toe; small landslide scars appear to have formed this steeper area and the deposits of these small landslides appear to have formed the colluvial apron (for example, see cross section A-A', pl. 1). These small landslide features, the amount of displacement that occurred at the landslide head, the geologic history of the area, and the lack of apparent landslide debris encountered by water well construction along the Florida River valley floor suggest that the older landslide occurred through nearly the present day slope toe and translated across the valley floor. Landslide debris along the valley floor was subsequently eroded by the river. An inferred profile of the older landslide soon after it was active is shown on cross section A-A' (pl. 1). The volume of landslide debris shown on the valley floor on the plate is consistent with the volume displaced at the landslide head. It appears that approximately $8.4 \times 10^{6} \mathrm{~m}^{3}$ of landslide debris have been eroded by the Florida River.

Earlier movement of the older landslide created fresh exposures of rock along the headscarp and a relatively flat bench with some closed depressions along the head of the landslide. EP-1 was excavated to a depth of $1.6 \mathrm{~m}$ within a closed depression located at the head of the older landslide deposit (pl. 1). This pit revealed several layers of organic-rich, fine-grained, and sandy sediment upon apparent sandstone bedrock. Charcoal was interspersed throughout much of the sediment. Charcoal samples obtained from the bottom of the pit returned a ${ }^{14} \mathrm{C}$ age of 1,670 +/- 40 years before present, which provides a calibrated age (CALIB, Stuiver and Reimer, 1993) of 1,424-1,696 years before present (two-sigma range). This is an approximate minimum age of the older landslide; there may have been a significant amount of time following initial landslide movement during which sediment was not deposited at the pit location, or our pit may not have reached the bottom of sediment deposited since landslide movement. A charcoal sample obtained from the top of the basal sediment layer exposed in the pit was also submitted for radiocarbon age determination. This sample returned a ${ }^{14} \mathrm{C}$ age of $195+/-35$ years before present, which provides a calibrated age of present day to 305 years before present (twosigma range). Younger radiocarbon samples such as this cannot be calibrated with a great degree of certainty because of $20^{\text {th }}$ century atmospheric pollution (for example, Trumbore, 2000).

Several areas within the older landslide have features suggestive of now dormant secondary landslide movement, that is, landslide activity that post-dates movement of the older landslide. These features include hummocky areas and apparent headscarps and landslide margins. The southern one-third of the older landslide appears to have moved as several large landslides after the initial older landslide became dormant, and these secondary landslides appear to have involved rock that underlies colluvium. The apparent headscarps of several apparently dormant shallow landslides were observed near the group of northern active landslides, and features suggestive of debris-flow activity were observed in this area in the 1966 aerial photographs. In addition, many of the standing dead trees in the north central part of the older landslide have trunks with upslope curvature, which may indicate past landslide activity or soil creep.

We installed two extensometers across the head of the older landslide (C-1 and C-6, pl. 1). We installed C-4 to evaluate potential reactivation of a large part of the older landslide. These extensometers have recorded no apparent landslide movement (fig. 14).

\section{Discussion}

\section{Shallow Landslides}

The steep slopes and the characteristics of colluvium and underlying bedrock present within the Florida River landslide 


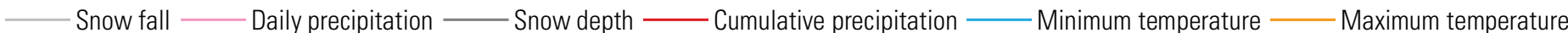

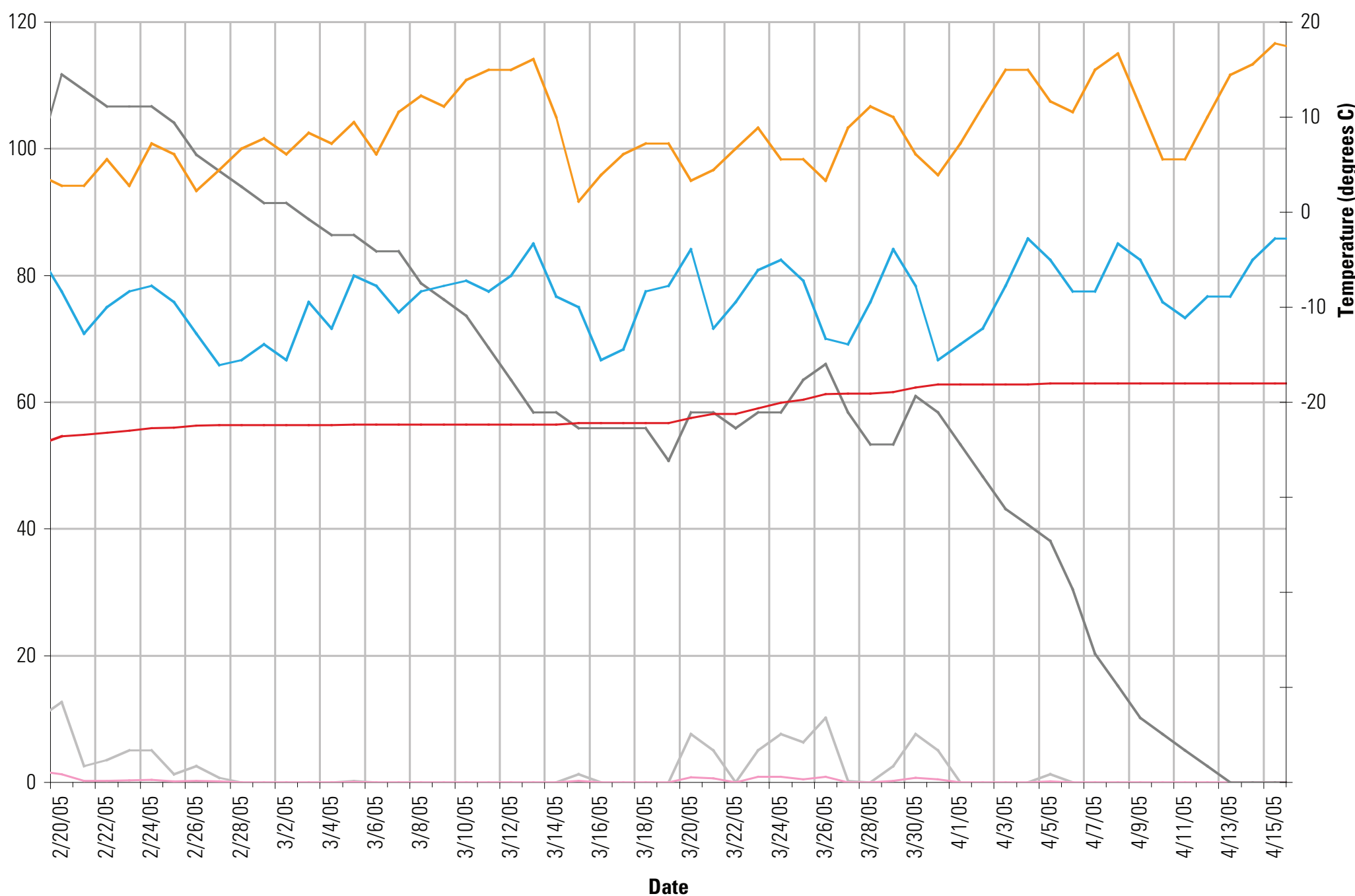

Figure 13. Climate data measured at Lemon Dam, February 20, 2005 - April 16, 2005 


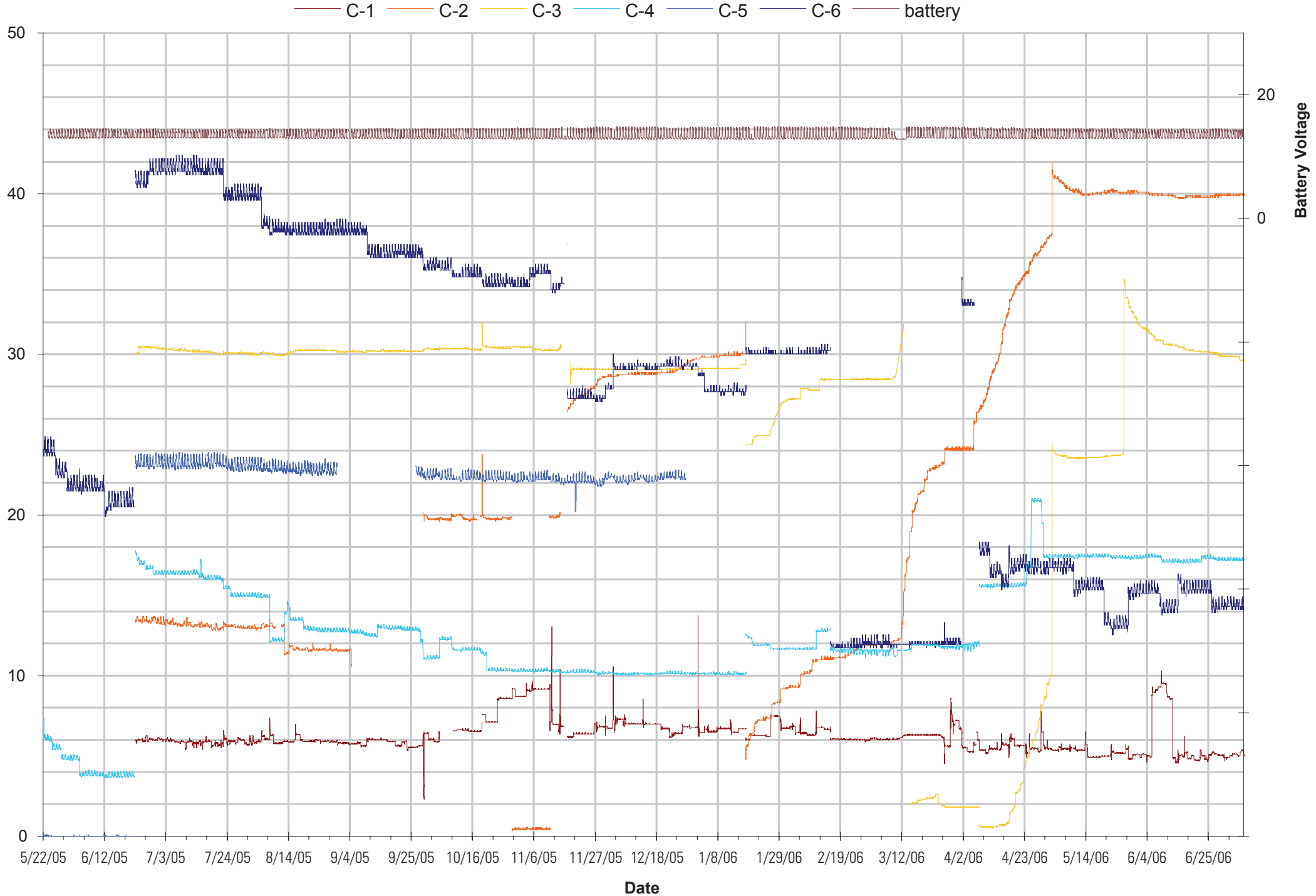

Figure 14. Extensometer (CET) data measured within the Florida River landslide complex, May 22, 2005 - July 7, 2006. 
- -1 , head —P-2, head —P-1, temp. — P-2, temp.

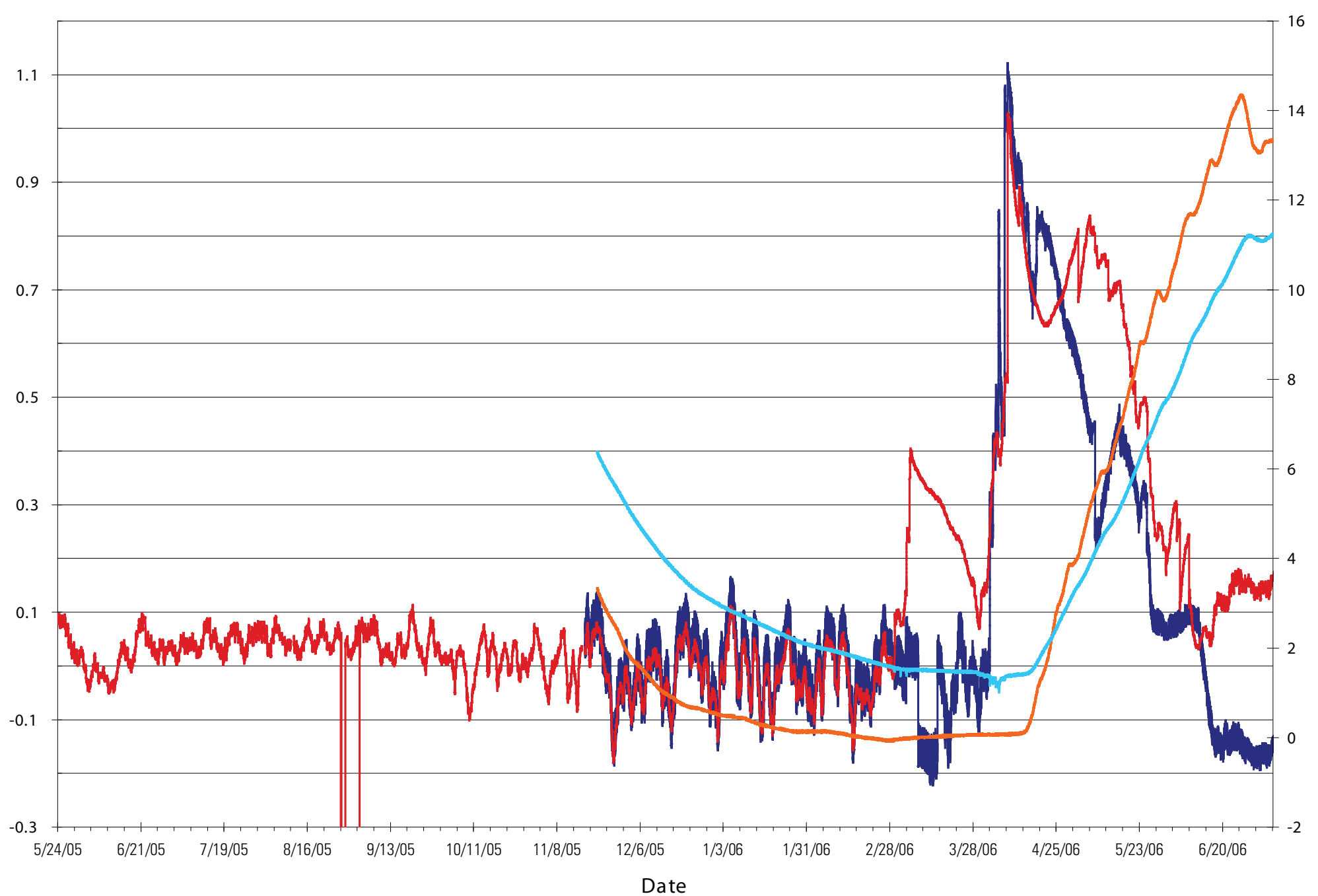

Figure 15. Piezometer data measured within the Florida River landslide complex, May 24, 2005 - July 7, 2006. 


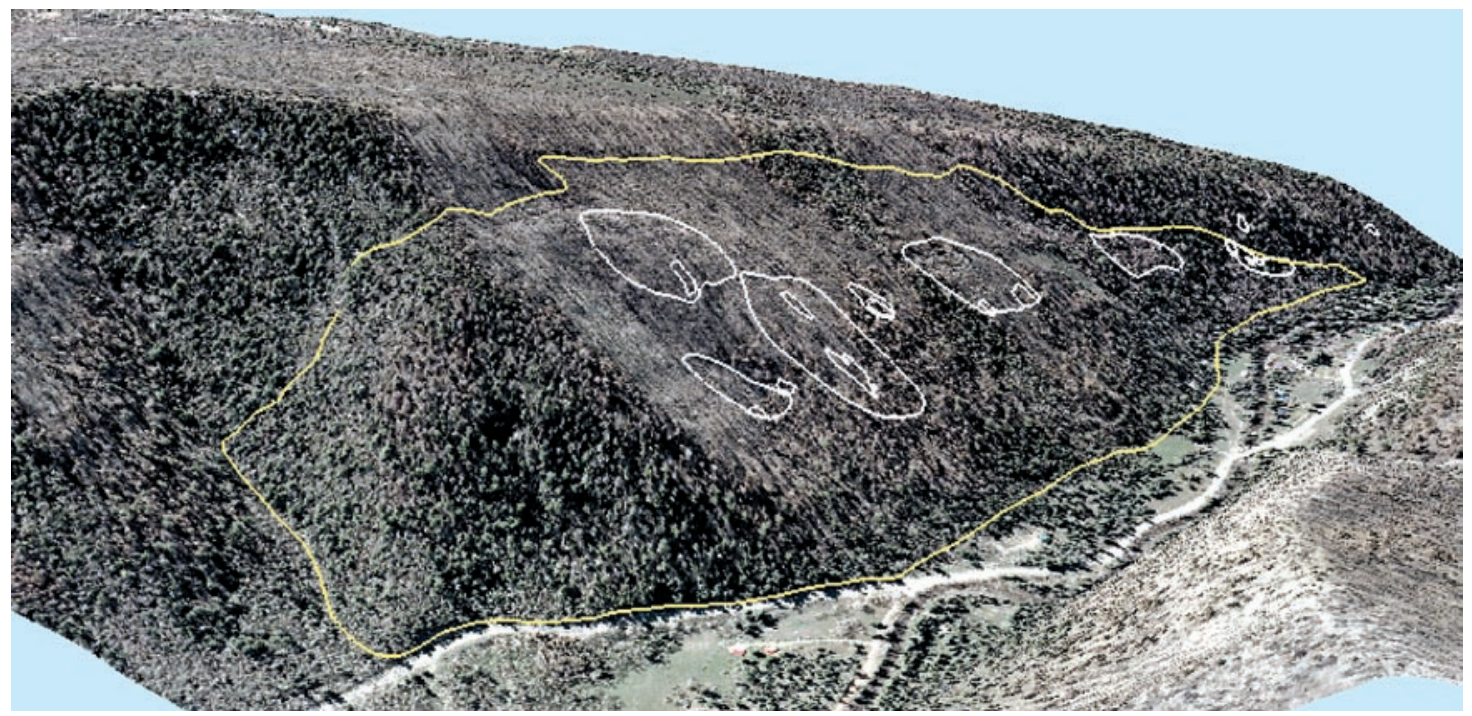

Figure 16. Virtual view to the southeast of the Florida River landslide complex. The older bedrock landslide is outlined in yellow and shallow landslides active during spring 2005 are outlined in white. View was created using a GIS by draping an orthophotograph and digital line graphs of mapped landslide boundaries onto the DEM.

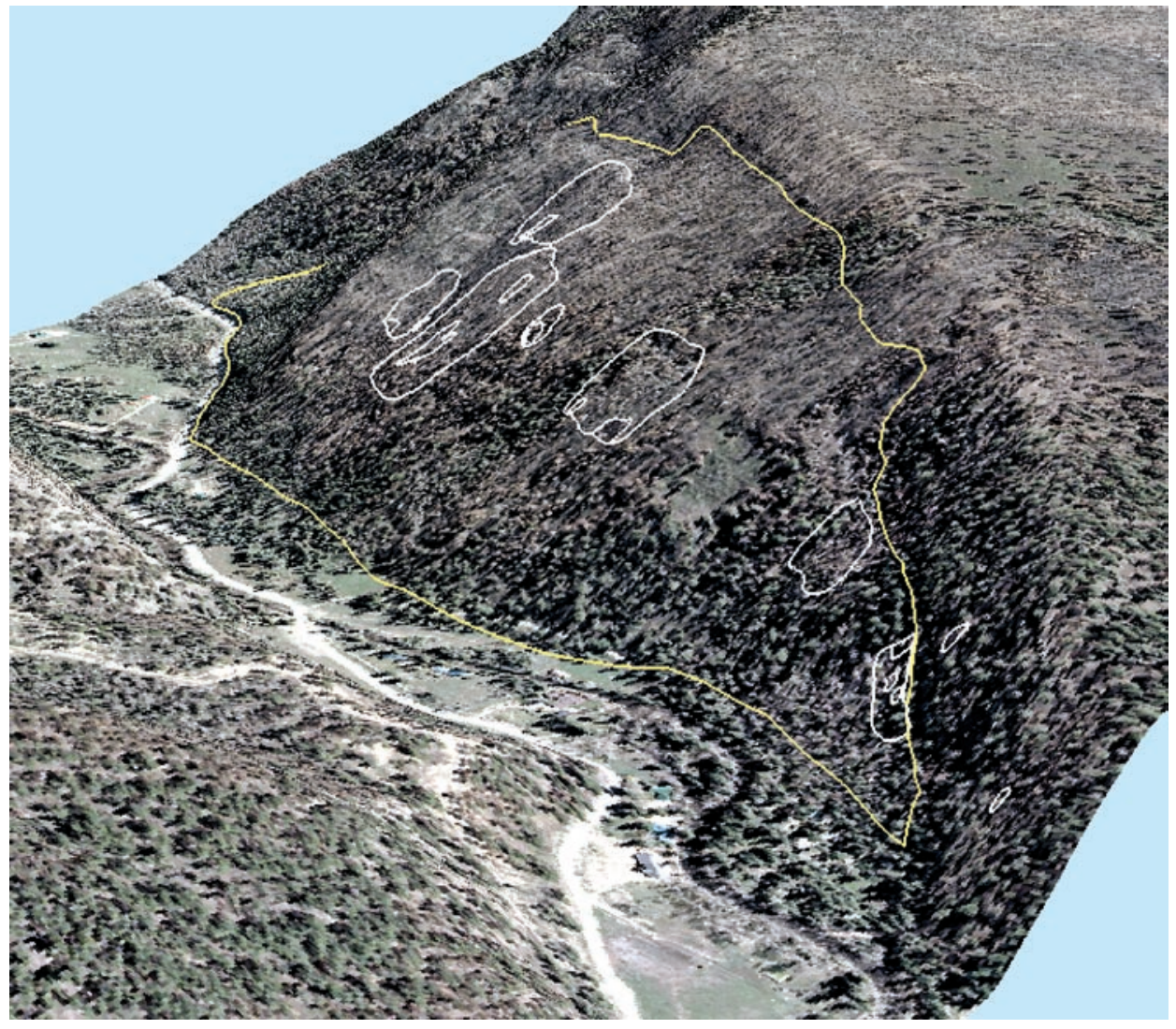

Figure 17. Virtual view to the northeast of the Florida River landslide complex. The older bedrock landslide is outlined in yellow and shallow landslides active during spring 2005 are outlined in white. View was created using a GIS by draping an orthophotograph and digital line graphs of mapped landslide boundaries onto the DEM. 
complex are conducive to the formation of shallow landslides. The potential for shallow landslide generation was increased by the 2002 Missionary Ridge wildfire. This fire caused the death of many trees on the hillside and an accompanying decrease of tree-root strength in colluvium, an increase in precipitation that reaches the ground surface, and a decrease in transpiration by vegetation. These latter two effects may have resulted in increased ground-water levels that could trigger landslides, while the decreased effective soil strength increased the potential for landslides. The causative effects of the fire on landslides may continue for perhaps another 20 years (DeGraff, 1997). Possible fire effects on landsliding within the landslide complex may best be illustrated by comparing precipitation and snowmelt records for water years 1992 (fig. 7) and 2004 (fig. 5 ). These 2 yrs had nearly equivalent releases of water during snowmelt, yet no landslides were reported during spring 1993 compared to the nearly two-dozen that occurred during spring 2005. In addition, three shallow landslides with approximate volumes of $30,000 \mathrm{~m}^{3}$ each, located on the hillside southeast of the left abutment of Lemon Dam, were activated during spring 2005. All these landslides occurred within areas burned by the Missionary Ridge fire; they are surrounded by areas little burned to unburned that lack landslides.

The type of shallow landslides within the landslide complex may experience alternating periods of activity and dormancy over many years. Some may go dormant and not reactivate, such as some apparently dormant shallow landslides located in the north-central part of the landslide complex that did not reactivate during spring 2005. Others may readily reactivate. The activity state of shallow landslides depends on local ground-water and loading conditions. Changes in loading typically require some outside influence such as earthwork operations or stream erosion, although landslide movement and debris-flow generation can greatly alter loading conditions. Changes in ground-water pressures are the most probable triggers of future shallow landslide activity within the landslide complex. Two snowmelt events that released 8 and $11 \mathrm{~cm}$ of water during late winter and early spring 2006 caused about a one-meter increase in ground-water level within the easternmost shallow landslide, but was apparently insufficient to reactivate the landslide.

Rainfall, as well as snowmelt, can cause increased ground-water pressures that result in landslide activity. Assuming that little snow melted, evaporated, or sublimated during winter 2004/05, spring 2005 snowmelt released approximately $45 \mathrm{~cm}$ of water during the 47-day snowmelt period of February 20 - April 8, 2005. These data provide an estimated snowmelt threshold and first approximation of the equivalent rainfall needed to result in shallow landslide formation within the landslide complex, assuming that all spring 2005 snowmelt infiltrated colluvium and that all future snowmelt and rainfall would as well. The 100-yr, 24-hr rainfall maximum (U.S. Department of Agriculture, 1967) for the landslide complex area is expected to be about $9 \mathrm{~cm}$. Colluvium within the landslide complex probably has a saturated hydraulic conductivity on the order of $9-900 \mathrm{~cm} / \mathrm{d}$ (Fetter, 1994, p.
98); so, assuming colluvium is moist to saturated, all rainfall from a 100 -yr storm should infiltrate the hillside. Therefore, given the assumptions made here, it is reasonable to assume that rainfall totals greater than $30 \mathrm{~cm}$ in one month may result in formation of new landslides within the landslide complex. The maximum 30-day rainfall total recorded at Lemon Dam since spring 2005 through May 2006 was $16.6 \mathrm{~cm}$ and the maximum since 1982 was $22.7 \mathrm{~cm}$. It is important to note that this approximate rainfall or snowmelt intensity of $30 \mathrm{~cm} /$ month that could potentially trigger shallow landslide activity is based on records for just one landslide event. Conditions prior to that event or future events are unknown. Ground water already present within colluvium combined with infiltration from lower rainfall intensities and durations than those given here could result in formation of new shallow landslides. The duration of rainfall or snowmelt necessary to increase groundwater levels sufficiently to trigger landslides is especially unclear. For example, the potential for shallow landslide activity triggered by snowmelt comparable to that of spring 2005 but occurring over a longer period is unknown.

Given that shallow translational landslides within the landslide complex typically are located far from residential structures, utilities, CR-243, and the Florida River, their movement poses little risk. However, these landslides commonly partly or wholly mobilize into debris flows. At this site debris flows can injure or kill humans, damage or destroy residential structures, CR-243, and utilities (mainly those located above ground), and could deposit debris in the Florida River. Position on the slope of the debris-flow source and debris-flow volume largely control the travel distance and velocity of debris flows, with larger debris flows on steeper slopes being more prone to travel farther at greater velocity. It appears likely that significant (above-average) snowmelt and rainfall events during the next two decades will trigger shallow landslides and debris flows within the landslide complex at a rate above that for unburned areas. These landslides and debris flows will probably be similar to those that occurred recently; however, only slightly larger debris flows than the recent flows could cause significant damage to residential structures and flow across CR-243 to the Florida River. The volumes of future individual debris flows will probably be less than about $5,000 \mathrm{~m}^{3}$.

An additional type of shallow landslide present within the landslide complex is rockfall from steeper parts of the hillside. Recent wildfire is unlikely to greatly increase the potential for this type of landslide. These topple and fall failures are localized when they occur and pose hazards mostly to humans in the immediate area. Residential structures located at the southern end of the landslide complex could conceivably be impacted by larger rockfalls than those that have been observed, although there appears to be a low potential for this to occur.

\section{Deep Landslides}

As with shallow landslides, deep landslides may experience alternating periods of activity and dormancy. The deep older landslide described herein is presently dormant. 
It appears that rising ground-water levels triggered previous activity of the older landslide; the older landslide may have occurred about 1,424-1,696 yrs ago and palaeoclimate studies have found that the climate in the area was wetter between about 2,650-1,250 yrs ago (Toney and Anderson, 2006). Wetter climatic conditions likely resulted in elevated ground-water levels. Slope-toe erosion that occurred about 11,000 yrs ago during glacial melt off (Atwood and Mather, 1932) probably changed slope-loading conditions and may have resulted in an inherently unstable slope that failed as ground-water levels rose during the wet period of 2,650-1,250 yrs ago. Renewed movement of the older landslide may be similarly triggered by changes in loading or rising ground-water pressures. Significant changes in loading of the older landslide are unlikely, given its location and the dam-controlled flow of the Florida River. Future climatic conditions will largely control groundwater conditions.

Little is known about the generation of deep landslides following wildfire. Soil reinforcement by tree roots has very little effect on large deep landslides so the decrease in root strength caused by the death of trees may not affect deep landslides. However, the loss of trees and other vegetation can result in increased ground-water levels because of the reduction of vegetation-related evapotranspiration (Cannon and others, 1998). Wildfire-dating activities in the nearby Los Piños River basin identified a wildfire $1,610+/-60{ }^{14} \mathrm{C}$ years before present (J.D. Frechette, University of New Mexico, written commun., 2006; Gonzales and others, 2003; Gonzales and others, 2005). This fire may have been the same as that which produced the charcoal we used to estimate the minimum age of the older landslide $\left(1,670+/-40{ }^{14} \mathrm{C}\right.$ years $)$. If so, a relatively widespread wildfire occurred prior to the older landslide. Any direct relationship between this wildfire and generation of the older landslide cannot be established with available data.

Upon slope failure, the older landslide probably crossed the valley floor quickly (less than several weeks, possibly within seconds) because the basal rupture of the older landslide cuts through many layers of rock. Landslides in rock often feature rapid, long runout because there is a significant decrease in rock strength once the rock is broken during failure. This strength decrease leaves the landslide with less-stable strength conditions than the hillside had prior to formation of the landslide. Erosion of landslide debris from the valley floor significantly changed loading conditions in the older landslide debris. The resulting configuration of landslide debris, without landslide debris to buttress the landslide toe, is likely less stable than prior to erosion.

Evidence that the older landslide dammed the Florida River is circumstantial. The landslide appears to have translated completely across the Florida River valley floor. If so, landslide debris dammed the Florida River and was subsequently eroded from this area by stream flow. The size, duration, and release characteristics of any water impoundment formed upstream of the landslide debris dam are unknown. Some landslide impoundments fail very rapidly, resulting in rapid impoundment drawdown and downstream flooding, while others fail gradually (Costa and Schuster, 1988).

The potential deep, secondary landslide area in the southern part of the older landslide does not have characteristics that strongly suggest a second episode of deposition of landslide debris across the Florida River valley floor. Secondary landslides may have occurred here, crossed the valley floor, and were subsequently eroded from this area. Alternatively, the southern end of the older landslide may have moved as several large blocks somewhat independently but contemporaneously with the older landslide resulting in one episode of landslide deposition on the valley floor. Also unclear are the boundaries of individual potential secondary landslides. The entire potential secondary landslide area involves about 7.7 $\mathrm{x} 10^{6} \mathrm{~m}^{3}$ of landslide debris and an additional $3.9 \times 10^{6} \mathrm{~m}^{3}$ of debris may have been eroded away by the river. As with the older landslide, rising ground-water levels probably triggered movement of potential secondary landslides from the southern part of the older landslide.

Future deep landslides will probably be triggered by rising ground-water pressures, because significant changes in hillside loading seem unlikely. However, any proposed earthwork on the hillside or excavations along the valley floor involving more than a few thousand cubic meters could be destabilizing. Evaluation of potential destabilizing effects is not covered herein, but could be conducted by a registered geotechnical engineer or engineering geologist. The Missionary Ridge wildfire will probably result in deep groundwater pressures greater than would have existed had the fire not occurred. The estimated time required for ground-water pressure increases to occur at the base of the older landslide following infiltration covers a broad range. For example, using published hydraulic conductivity values for Entrada Sandstone and the Morrison Formation (Frenzel and Lyford, 1982) and a vertical downward ground-water flow gradient, we estimate that spring 2005 snowmelt will affect ground-water pressures at the base of the older landslide between 0.7-300 yrs from when melt occurred. In the absence of detailed landslide strength and hydrologic data, it is unknown whether groundwater pressure increases resulting from spring 2005 snowmelt will be great enough to trigger renewed deep landslide activity.

Future deep landslide activity will probably involve movement along the base of the older landslide because this previously sheared area likely has much lower strength than that of overlying, relatively unsheared rock and because regional ground-water rise often results in ground-water pressure increase first at relatively greater depth. Renewed landslide activity along the existing basal rupture of the older landslide should occur gradually because peak strength of the rock has already been overcome. However, the La Conchita, California landslide of January 2005 was a reactivation of a deep landslide (although it may not have reactivated along the pre-existing basal shear zone), yet it occurred very rapidly and destroyed or damaged 36 homes and killed 10 people (Jibson, 2005). Renewed activity of the older landslide could be indicated by ground deformation (cracks, uplift, subsidence, horizontal 
offsets), distress to residential structures, CR-243, or utilities located at the base of the slope, or the emergence of previously unknown springs. Renewed landsliding could involve the entire older landslide or significant parts thereof. Apparently wetter conditions and the relatively greater inclination of the area near cross section A-A' (pl. 1) suggest that this area may be most prone to partial reactivation, but the data are much too incomplete to estimate the potential for reactivation and its configuration. Partial or complete reactivation of the older landslide could result in volumes of landslide debris crossing the valley floor that are similar to the volumes that appear to have crossed the floor previously. Reactivated landslide debris would consist mainly of large blocks (meters across) of rock with silty sand, clayey sand, and gravel, and would likely be very unstable. Excavation of landslide debris from the valley floor could be a very dangerous operation and would likely cause additional landslide movement.

\section{Potential Additional Investigations}

Shallow landslide activity and resultant debris flows will likely continue within the Florida River landslide complex during the next two decades and will probably follow periods of significant precipitation and snowmelt. The potential for partial or entire reactivation of the deep older landslide cannot presently be quantified or estimated with confidence. However, the consequences of deep landsliding within the landslide complex appear to warrant additional investigation. Possible additional activities that could be undertaken to better understand the potential for deep landslide reactivation are provided below.

Warning of incipient landslide movement and increased understanding of future landslide activity, should it occur, can be obtained by revising the monitoring system. Extensometers C-4 and C-5 could be moved to areas across the southern part of the older landslide headscarp and the southern secondary landslide area. Biaxial, electronic clinometers could be installed on rock that underlies colluvium along the older landslide head to detect extremely small variations in orientation and thus provide data indicating landslide reactivation that would augment extensometer data. Clinometers and extensometers that are located more than about one-hundred meters from the datalogger (C-4, C-5, and C-6) could be equipped with remote power, dataloggers, and communication systems with which to communicate with the master datalogger. These remote systems should increase equipment reliability and resolution. The survey monuments we installed (Table 1) could be resurveyed on a regular basis to detect landslide movement in areas not monitored by extensometers and clinometers.

Additional characterization of the age(s) of past landslide activity could be undertaken. This characterization would involve soil sampling and radiocarbon testing. Samples could be obtained from the base of soil pits excavated to permit clinometer installation. Radiocarbon test results evaluated alongside results of previous climatic studies could provide better understanding of the potential for future landslide activity by suggesting conditions resulting in previous landslide movement episodes and the boundaries of secondary landslides.

The nature of a potential future landslide-related impoundment of the Florida River could be better understood by identifying the size and nature of previous impoundment(s). Characteristics of previous impoundments could be studied by geologic mapping and subsurface exploration upstream from the landslide complex to potentially identify the existence and boundaries of lacustrine deposits, and mapping the lower part of the slope opposite the landslide complex across the Florida River to possibly identify the characteristics and extent of landslide debris that may remain. Downstream areas could be examined for features indicative of rapid failure of previous impoundment(s), such as erosional features or changes in the slope of the Florida River thalweg.

The boundaries and characteristics of deep secondary landslides within the landslide complex could be better understood by obtaining and evaluating large-scale stereoscopic aerial photographs and topographic data derived from these photos, or high-resolution topographic data (for example, airborne or ground-based light distance and ranging [LIDAR] data). High-resolution topographic data would also be needed to accurately model the landslide complex.

Deep rock strength and hydrologic data from within the older landslide could be obtained by constructing a series of deep boreholes and ground-water monitoring wells across the landslide area and by laboratory tests performed on samples from these boreholes. Trenches or pits excavated into rock could also provide useful subsurface data where landslide debris is thin, such as at the landslide head or toe. Presumably lower quality laboratory test results could be acquired from tests of rock samples obtained from shallow boreholes, trenches, or pits advanced into the landslide.

In the absence of additional data, two deep landslide hazard mitigation alternatives seem reasonable to consider. Should it occur, deep landslide activity will probably be caused by ground-water levels that may increase in the future. Therefore, construction of horizontal drains at the slope toe or other devices to remove ground water from the older landslide and underlying bedrock could reduce the potential for landslide generation or reactivation. In addition, hazards related to damming of the Florida River by landslide debris might be reduced by encasing river flow within structures designed to withstand the loads imposed by potential landslide debris, or by construction of structures designed to convey reservoir discharge outside of the area that could be impacted by potential future deep landslide activity. Landslide mitigation planning could include a registered geotechnical engineer or engineering geologist to evaluate specific concerns.

\section{Conclusion}

Above-average snowmelt during spring 2005 triggered nearly two-dozen landslides on a hillside located along the east side of the Florida River about one kilometer downstream 
from Lemon Reservoir in La Plata County, Colorado. Much of the hillside where the landslides occurred was burned by the 2002 Missionary Ridge wildfire. We assessed the landslide activity and associated hazards at the request of the FWCD, La Plata County, USBR, and the city of Durango. Our assessment included geologic mapping, subsurface exploration and sampling, radiocarbon dating, and shallow ground-water and ground-displacement monitoring.

Landslides that occurred on the hillside during spring 2005 were generally shallow translational landslides involving colluvium moving along its basal contact with underlying rock. Nearly all of the landslides partly to completely mobilized as debris flows, some of which traveled as far as the Florida River valley floor. Fast-moving debris flows are capable of killing or injuring humans, destroying or damaging residential structures, burying CR-243 and striking pedestrians or vehicles, and depositing debris into the Florida River and across the valley floor. The spring 2005 landslides were likely triggered by elevated ground-water pressures that developed as snowmelt infiltrated colluvium and perched upon underlying rock. Landslide activity stopped as ground water drained from the colluvium. Shallow landslide activity in the area was probably more pronounced than in adjacent areas because of the loss of tree root strength and reduced evapotranspiration by plants on the hillside due to the Missionary Ridge fire. These fire effects may contribute to shallow slope instability for another two decades. Based on our observations and monitoring results, we developed an approximate rainfall/snowmelt threshold above which shallow landslide activity may be expected. This threshold is based on only one event, so it should not be relied upon for decision making. It appears that new shallow landslides may develop following about $30 \mathrm{~cm}$ of rainfall or snowmelt that occurs within about one month.

Landslides triggered during spring 2005 occurred within a very large older landslide (19.7 million cubic meters) that extends, on average, about $40 \mathrm{~m}$ into bedrock. This landslide appears to be dormant and may have occurred about 1,4241,696 years ago. This time period was wetter than the previous period, which may have caused increased ground-water pressures thereby triggering the original landslide. Also, relatively widespread wildfire may have occurred shortly before this landslide formed, which could have contributed to deeper slope instability by indirectly increasing ground-water pressures. Once triggered, the landslide moved about $150 \mathrm{~m}$ and appears to have blocked the Florida River valley floor with about $8.4 \mathrm{x}$ $10^{6} \mathrm{~m}^{3}$ of landslide debris. Landslide debris may have temporarily impounded the Florida River and was subsequently eroded away, leaving the landslide with a potentially less stable configuration. Characteristics of any past impoundment of the river and failure of the impoundment are unknown. In addition to this landslide movement episode, it appears that deep secondary landsliding may have occurred near the southern end of the older landslide. Rock strength and ground-water conditions are unknown within and beneath the older landslide; therefore, the potential for future deep landsliding is unknown but is probably lower than for future shallow landsliding.
If continued, near real-time monitoring of shallow ground water and localized ground displacement on the hillside could provide notification of the onset of landslide activity, both shallow and deep. The near-real-time displacement-monitoring devices provide localized data mostly along the head of the older landslide; hence, the survey monuments that we installed across the entire older landslide should be episodically surveyed and compared to past measurements to detect possible landslide activity across a larger area. Additional assessment activities could be undertaken to better understand the hazards presented by the landslide complex. These activities could include obtaining detailed topographic data and aerial photography, mapping to identify landslide debris and lacustrine deposits formed within a potential former impoundment of the Florida River, mapping secondary landslides, obtaining additional ages of buried soils, construction of deep boreholes and ground-water monitoring wells, laboratory testing, and ground-water and slope-stability modeling.

\section{Acknowledgments}

This project benefited from collaboration with many people and different agencies. We wish to thank the following individuals (in no particular order) for their contributions and apologize for any omissions: John Ey of FWCD for his assistance and collaboration in nearly all aspects of our assessment; N.D. Knowlton of La Plata County for background information and logistical support; Roberto and Yvonne Siragusa, Patrick and Pamela Johnson, Robert Edsall, Jr., and Bruce and Maria Stanley for access to their properties; Jonathan McKenna and Joseph Gartner of USGS, Danny Powers, Travis Clark, and Jeff Sonheim of FWCD, Silvia Simoni of the University of Trento, Italy, Andrew Gleason with the Colorado Geological Survey, and Cathleen Zilich of the USFS for assistance with field work; Mark Radosevich for background information; Alan Andrews and Rob Bergstrom of La Plata County for GIS data, assistance with data processing, and information regarding additional data availability; David Grey and Mark Gress of USGS for A-15 rain-gage data; Jedediah Frechette of the University of New Mexico, Erica Bigio of the University of Arizona, and Jaime Toney of Northern Arizona University for wildfire history data; Susan Cannon of USGS for various information regarding geology and wildfire; Alan Nelson of USGS for assistance with radiocarbon dating; Dr. Scott White, Dr. Darren Cookus, and Dr. Ray Kenny of Fort Lewis College for assistance with aerial photography; Burt Ives of USBR for survey monument data; and Erik Zinn of Zinn Geology for advice and insight. Mark Reid, Robert Schuster, and Rex Baum (USGS) provided insightful, constructive reviews of this report. 


\section{References Cited}

American Society for Testing and Materials, 2002, Annual book of ASTM Standards, v. 4.08: Philadelphia, Pa., American Society for Testing and Materials, $1672 \mathrm{p}$.

Atwood, W.W., and Mather, K.F., 1932, Physiography and Quaternary geology of the San Juan Mountains, Colorado: U.S. Geological Survey Professional Paper 166, 176 p.

Bates, R.L., and Jackson, J.A., 1987, Glossary of geology: Alexandria, Va., American Geological Institute, 788 p.

Bigio, Erica, Swetnam, Tom, and Baisan, Chris, 2005, The integration of tree-ring and alluvial fan records of fire history at the Missionary Ridge fire near Durango, Colorado [abs.]: Geological Society of America Abstracts with Programs, v. 37, no. 7, p. 111.

Birkeland, P.W., 1999, Soils and geomorphology ( $3^{\text {rd }}$ ed.): New York, Oxford University Press, 431 p.

Blair, Rob, 1977, Surficial geologic map and geologic hazards map of Rules Hill quadrangle: unpublished map prepared by Four Corners Environmental Research Institute for La Plata County Planning Department, scale 1:24,000.

Cannon, S.H., 2001, Debris-flow generation from recently burned watersheds: Environmental and Engineering Geoscience, v. 7, no. 4, p. 321-341.

Cannon, S.H., Ellis, W.L., and Godt, J.W., 1998, Evaluation of the landslide potential in Capulin Canyon following the Dome Fire, Bandelier National Monument, New Mexico: U.S. Geological Survey Open-File Report 98-42, 21 p.

Cannon, S.H., and Gartner, J.E., 2005, Wildfire-related debris flow from a hazards perspective, in Jakob, Matthias, and Hungr, Oldrich, eds., Debris-flow Hazards and Related Phenomena: Berlin, Springer, p. 363-385.

Cannon, S.H., Gartner, J.E., Holland-Sears, A., Thurston, B.M., and Gleason, J.A., 2003, Debris-flow response of basins burned by the 2002 Coal Seam and Missionary Ridge fires, Colorado, in Boyer, D.D., Santi, P.M., and Rogers, W.P., eds., Engineering Geology in Colorado-Contributions, Trends, and Case Histories: AEG Special Publication 14, on CD-ROM.

Carroll, C.J., Kirkham, R.M., and Wracher, Andrew, 1997, Geologic map of the Rules Hill quadrangle, La Plata County, Colorado: Colorado Geological Survey, scale 1:24,000.

Coe, J.A., Godt, J.W., Ellis, W.L., Savage, W.Z., Savage, J.E., Powers, P.S., Varnes, D.J., and Tachker, P., 2003, Seasonal movement of the Slumgullion landslide as determined from Global Positioning System surveys and field instrumentation, July 1998 - March, 2002: Engineering Geology, v. 68, pp. 67-101.
Costa, J.E., and Schuster, R.L., 1988, The formation and failure of natural dams: Geological Society of America Bulletin, v. 100, p. 1054-1068.

DeGraff, J.V., 1997, Geologic investigation of the Pilot Ridge debris flow, Groveland Ranger District, Stanislaus National Forest: U.S. Department of Agriculture, Forest Service, $20 \mathrm{p}$.

Fetter, C.W., 1994, Applied hydrogeology: New York, Macmillan, $691 \mathrm{p}$.

Frechette, J.D., Gonzales, D.A., Kenny, Ray, and Thompson, J.R., 2003, Evidence for a connection between wildfires, erosion, and landscape development over the past 3600 years in southwestern Colorado [abs.]: Geological Society of America Abstracts with Programs, v. 35, no. 6, p. 36.

Frenzel, P.F., and Lyford, F.P., 1982, Estimates of vertical hydraulic conductivity and regional ground-water flow rates in rocks of Jurassic and Cretaceous age, San Juan Basin, New Mexico and Colorado: U.S. Geological Survey WaterResources Investigations 82-4015, 59 p.

Gili, J.A., Corominas, J., and Rius, J., 2000, Using Global Positioning System techniques in landslide monitoring: Engineering Geology, v.55, p.167-192.

Gonzales, D.A., Frechette, J.D., Starr, D.W., III, Osmerra, T., Morse, N., and Graham, K., 2005, Geologic map of the Vallecito Reservoir quadrangle, La Plata County, CO: Colorado Geological Survey OF04-09, scale 1:24,000.

Gonzales, D.A., Matthews, Vincent, III, and Frechette, J.D., 2003, Insight into a record of fire and related debris flows in southwestern Colorado: Using geologic mapping and field studies to understand the past and to predict future events [abs.]: Geological Society of America Abstracts with Programs, v. 35, no. 6, p. 69.

Jackson, M.E., Bodin, P.W., Savage, W.Z., and Nel, E.M., 1996, Measurement of local velocities on the Slumgullion landslide using the Global Positioning System, in Varnes, D.J., and Savage, W.Z., eds., The Slumgullion earth flow: A large-scale natural laboratory: U.S. Geological Survey Bulletin 2130, p. 93-95.

Jibson, R.W., 2005, Landslide hazards at La Conchita, California: U.S. Geological Survey Open-File Report 20051067, 12 p.

Leick, A., 1990, GPS satellite surveying: New York, Wiley and Sons, $352 \mathrm{p}$.

Malet, J.P., Maquaire, O., and Calais, E., 2002, The use of Global Positioning System techniques for the continuous monitoring of landslides - application to the Super-Sauze earthflow (Alpes-de Haute-Provence, France): Geomorphology, v. 43, p. 33-54. 
Naval Facilities Engineering Command, 1986, Soil mechanics, design manual 7.01: Alexandria, Va., Naval Facilities Engineering Command, $348 \mathrm{p}$.

Shaub, Suzanne, 2001, Landslides and wildfire: an example from the Boise National Forest: Boise, Idaho, Boise State University, M.S. thesis, 85 p., 1 pl., 21 figs.

Smith, M.E., Elliot, J.G., Friedel, M.J., Litke, D.W., Stevens, M.R., Costello, C., Char, S.J., and Wagner, J., 2003, Postfire hydrologic hazards study for the 2002 Hayman, Coal Seam, and Missionary Ridge wildfires, Colorado: U.S. Geological Survey Administrative Report, 49 p.

Steven, T.A., Lipman, P.W., Hail, W.J., Jr., Barker, Fred, and Luedke, R.G., 1974, Geologic map of the Durango quadrangle, southwestern Colorado: U.S. Geological Survey Miscellaneous Investigations Series Map I-764, scale 1:250,000.

Stuiver, M., and Reimer, P. J., 1993, Extended 14C database and revised CALIB radiocarbon calibration program: Radiocarbon, v. 35, p. 215-230.

Toney, J.L., and Anderson, R.S., 2006, A postglacial palaeoecological record from the San Juan Mountains of Colorado USA: fire, climate, and vegetation history: The Holocene, v. 16 , no. 4 , p. 505-517.

Trumbore, S.E., 2000, Radiocarbon geochronology, in Noller, J.S., Sowers, J.M., and Lettis, W.R., eds., Quaternary geochronology: methods and applications: Washington D.C., American Geophysical Union, p. 41-60.

Tweto, Ogden, 1975, Laramide (Late Cretaceous-Early Tertiary) orogeny in the southern Rocky Mountains: U.S. Geological Survey Memoir 144, 44 p.

U.S. Department of Agriculture, 1967, 24-hour rainfall May-October 1 percent probability, Colorado: USDA Soil Conservation Service rainfall map, unscaled.

U.S. Forest Service, 2002, Burned area emergency stabilization and rehabilitation plan, Missionary Ridge and Valley Fires: U.S. Department of Agriculture, http://www.fs.fed. us/r2/sanjuan/fire/missridge/baerreport.htm (accessed December 14, 2005), not paginated.

Van Sickle, J., 1996, GPS for land surveyors: Chelsea, Michigan, Ann Arbor Press, 209 p. 